\title{
The Greening of Boston: Trees and Shrubs in the City
}

\section{$D 14$ B65F}

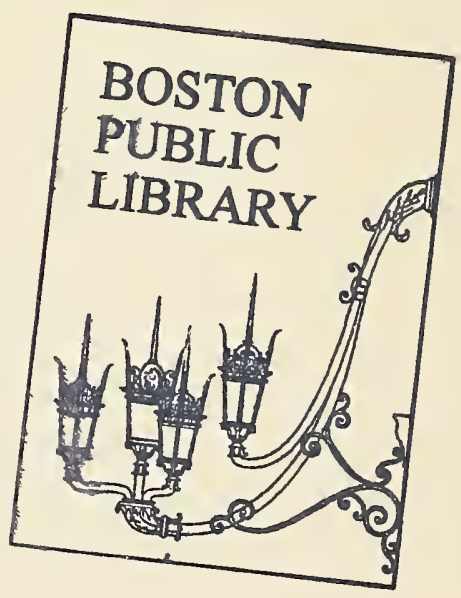


The Greening of Boston:

Trees and Shrubs in the City

\section{D14 The Boston \\ B65F Foundation.}

AUTHOR

The Greening of Boston:

Trees and Shrubs in the City.

D14

B65F

The Boston Foundation.

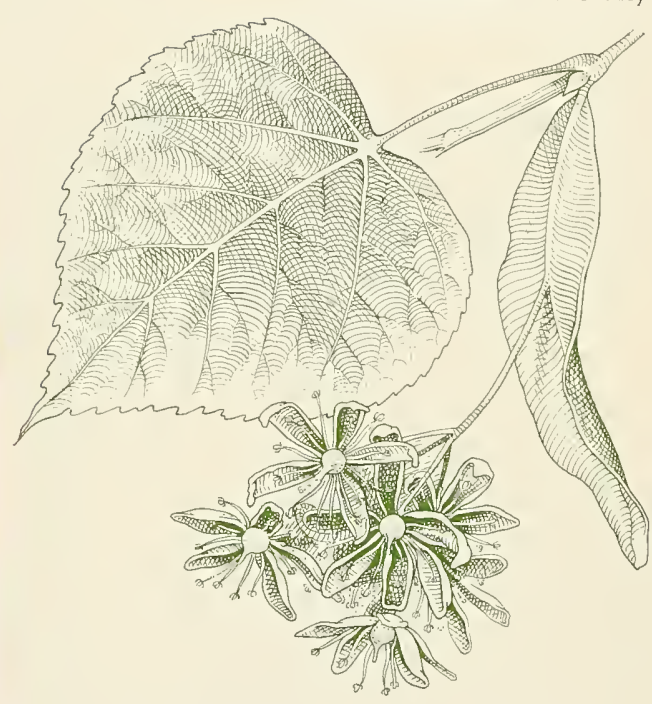


Boston is a green city. Everywhere one encounters trees and shrubs that have adapted to life in this densely populated urban area. The greening starts in the Common and the Public Garden. From there it extends down Commonwealth Avenue to the Fens, and then to Jamaica Pond, the Arboretum, and Franklin Park. This "Emerald Necklace" is highly visible; but it is in the small parks and squares and along the streets of Boston's neighborhoods that people have more frequent daily contact with the pleasure and beauty of trees, shrubs, and flowering plants.
Boston's first urban planners wanted to create a healthy and diverse environment for people in the city. Their early achievements have been sustained by generations of residents who committed their civic energy to planting trees along city streets and establishing green spaces. Today we recognize just how much the people of Boston use and enjoy plants. Trees and shrubs provide shade, windbreaks, and privacy; they have practical value to the city dweller. They have aesthetic value as well; their masses of green foliage, seasonal flowers, fall color, and winter silhouettes add greatly to our visual appreciation of the city.

The fact that plants now surround us should not be taken for granted. The greening of a city is a process. Like the recycling of old buildings and the reshaping of city neighborhoods, greening requires energy and imagina- tion on the part of each new generation. Planting trees and shrubs is not a task that, once completed, can be ignored. It takes ongoing effort to keep plants thriving in any urban setting.

This publication has been prepared for the residents of Boston. It is a guide to the best trees and shrubs for planting in the city plants that are hardy, tenacious, and pleasing to the eye. Basic methods of care and feeding are also described. We want to encourage residents all over the city to plant trees and shrubs, and to help maintain new and old plantings in the face of urban stresses. The greening of the urban landscape continues to depend on people.

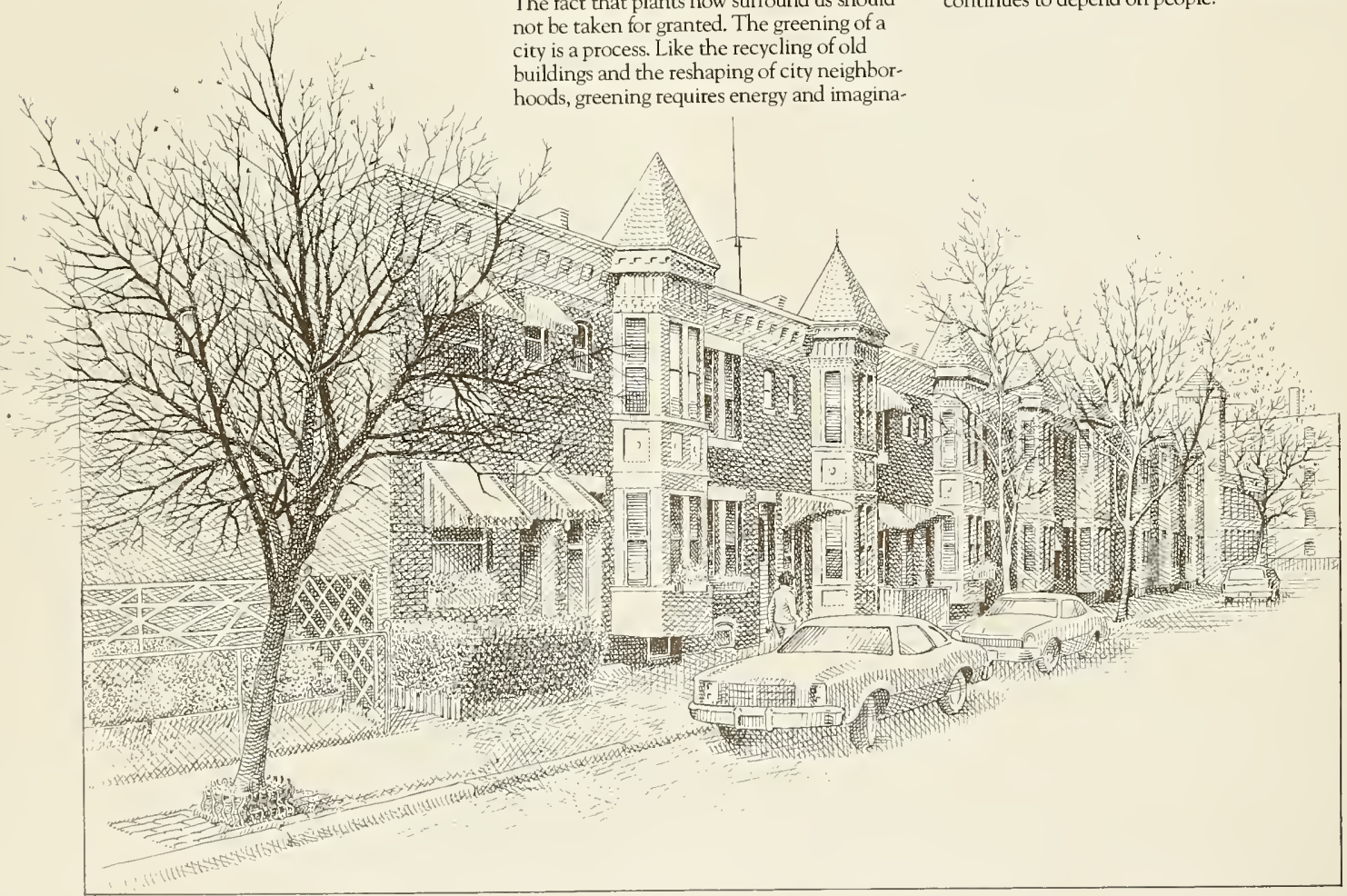




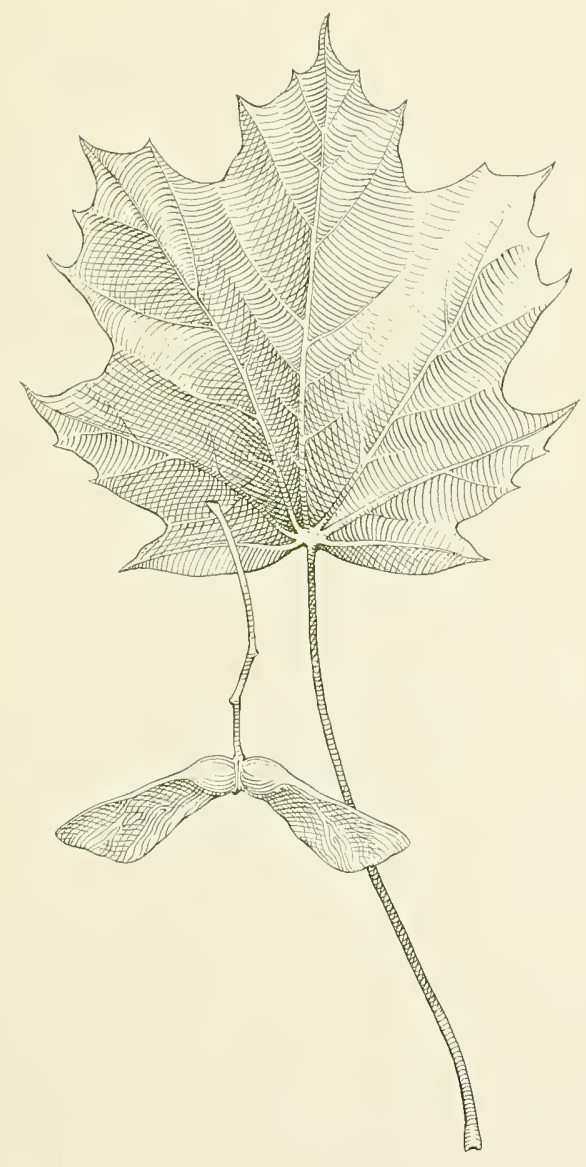

\section{Plants in an Urban Environment}

Sunlight, temperature, wind, rain, and snowfall are variable weather conditions that make climate. They affect what plants we can grow and where we can grow them.

Cities such as Boston are generally warmer than the surrounding suburbs. To the city dweller this means earlier blossoms and longer periods free of frost. In the early spring, commuters notice that daffodils and forsythia are blooming in Boston but still dormant in the suburbs. Trees leaf out earlier in the city than in the suburbs. This phenomenon is caused by the "urban heat island." The "island" is warmed by the tremendous energy pouring out of industries, by commercial and residential heating systems, and by the release of heat stored in building and pavement surfaces. Rainwater, which cools suburban land surfaces, disappears quickly down city gutters and catch basins. Even the cloud of pollutants, hovering over the city like an insulating blanket, holds in heat.

Boston's weather is notoriously changeable. Our prevailing west-to-east weather flow collides periodically with air movements coming down from Canada and up from the tropics, producing sudden changes. Boston's seacoast position also subjects it to coastal storms, "northeasters," which bring strong winds and heavy rain or snow. The Atlantic Ocean moderates temperature extremes: Boston's famous sea breezes cool steamy summer afternoons, while the relatively warm seawater lessens the severity of winter cold.

Plants moderate the effects of city climate. Deciduous trees provide cooling shade, while evaporation of water from their leaf surfaces helps to lower summer temperatures. In winter, the same trees allow warming sunlight to shine through their leafless branches onto streets, sidewalks, buildings, and into windows. Trees and shrubs can also control and redirect harsh winds, making walking more pleasant for pedestrians. 
Trees and shrubs help reduce urban pollution. Plants are natural filters. They take carbon dioxide from the air and return oxygen to it; they also remove limited quantities of sulphur dioxide and hydrogen fluoride, which are common pollutants, from city air. Plants filter out dust, pollen, ash, and smoke by trapping airborne particles on the tiny hairs that coat their leaves. The particles are regularly washed off onto the ground by rainfall. Plants also decrease other urban irritants such as noise and light glare. Tree trunks and large branches somewhat disperse sound waves, while leaf masses absorb them. Light glare is reduced by trees and shrubs that screen automobile headlights, streetlights, floodlights, and obtrusive neon signs. Plants of the proper size, shape, and density can be used effectively to lessen many disturbing qualities of city life.

Birds and other wildlife survive in the city because trees and shrubs offer them food, shelter, and breeding places. Squirrels, pigeons, and other birds - even an occasional rabbit - help animate the city and make the out-of-doors more interesting. Boston's green spaces attract both local and migratory birds. A great variety of visiting waterfowl is observed annually on Boston's rivers and ponds and in the Fens. In every part of the city where green spaces are preserved, different species of landbirds are commonly seen. From time to time, the Massachusetts Audubon Society issues reports of unusual bird sightings in Boston and its vicinity: barred owls in Cambridge, cerulean and yellow-throated warblers in Mt. Auburn Cemetery, a gyrfalcon at the Prudential Center! Plants are essential to attract and protect resident and visiting wildlife. Especially important are native fruit-bearing trees and shrubs.

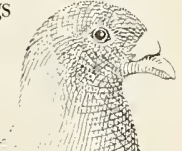

Trees and shrubs make an important contribution to the architecture of urban spaces. Their shapes complement buildings, both old and new. Their textures and shadows enhance the variety of building materials in the city: brick, wood, stone, concrete. Trees and shrubs also provide a comfortable transition from the human to the larger building scale. In parks and gardens, they form areas of privacy and places for retreat from intense city activity.

Each day, trees and shrubs give the city dweller the opportunity to observe the processes of nature: subtleties of seasonal change, plant growth, and the varying characteristics of plant shape, texture, flowers, and fruit. But unlike forests, wetlands, and prairies, the city's green spaces are not self-sustaining. They are remote from the more balanced ecology of rural lands and are dependent on human care.

Trees and shrubs can be successfully grown in the city only when urban stresses are understood and countered with responsible planting and maintenance. Plants do not thrive when the light they need is blocked by buildings, when they receive insufficient water, or when they suffer in compacted soil. The need for sunlight and water is common knowledge. Less well-known is the fact that compacted soil limits the circulation of air around roots, and that this air-or the oxygen in it - is critical to the survival of any plant. Additionally, salt used for de-icing streets and sidewalks is particularly harmful to the root structure of trees and shrubs, quickly killing the surface roots and eventually affecting the entire plant.

The list of hazards to trees and shrubs in the city is long: excessive air pollution, poor soil, wounds from cars and trucks, vandalism, and carelessness during construction. These stresses damage and kill plants; they also weaken their natural resistance to insect attacks and disease. But most of these threats to city plants can be avoided by proper planting and care. Informed residents can be aware of the health and well-being of their neighborhood trees and shrubs. And most important, they can participate in the simple tasks that preserve the lives of plants and enhance their natural growth and beauty. 


\section{Trees and Shrubs Recommended for Planting in Boston}

\section{Street Trees}

Ginkgo

(Ginkgo biloba)

Green Ash

(Fraxinus pennsyluanica lanceolata)

Katsura

(Cercidiphylhum japonicum)

Little-leaf Linden

(Tilia cordata)

London Plane

(Platanus acerifolia)

Norway Maple

(Acer platanoides)

Pin Oak

(Quercus palistris)

Red Oak

(Quercus borealis)

Sweet Gum

(Liquidambar styraciflua)

Sycamore Maple

(Acer pseudoplatanus)

Thomless Honey Locust

(Gleditsia triacanthos inermis)

Tree of Heaven

(Ailanthus altissima)

Japanese Zelkova

(Zelkova serrata)
Ornamental Trees

Amur Maple

(Acer ginnala)

Bradford Callery Pear

(Pyrus calleryana 'Bradford')

Cornelian Cherry

(Comus mas)

Crab Apple

(Malus varieties)

Flowering Dogwood

(Comus florida)

Hawthom, Washington and Lavalle

(Crataegus phaenopyrum.

Crataegus lavallei)

Japanese Dogwood

(Comis Kousa)

Magnolia, Saucer and Star

(Magnolia soulangiana

Magnolia stellata)

\section{Evergreen Trees}

Austrian Pine

(Pinus nigra)

Hemlock, Canadian and Carolina (Tsuga canadensis,

Tsuga caroliniana)

Japanese Black Pine

(Pinus thunbergii)

White Fir

(Abies concolor)
Deciduous Shrubs

Chinese Witch Hazel

(Hamamelis mollis)

Cotoneaster, Rock and Spreading

(Cotoneaster horizontalis,

Cotoneaster divaricata)

Flowering Quince

(Chaenomeles varieties)

Forsythia

(Forsythia intermedia, Forsythia

'Amold Dwarf)

Japanese Green Barberry

(Berberis thunbergii)

Lilac

(Syringa varieties)

Rose of Sharon

(Hibiscus syriacus)

Scarlet Firethorn

(Pyracantha coccinea)

Spirea

(Sprraea varieties)

Viburnum

(Viburntm varieties)
Broad-Leaved

Evergreen Shrubs

Azaleas

(Rhododendron varieties)

Inkberry

(Ilex glabra)

Japanese Holly

(llex crenata)

Mountain Andromeda

(Pieris floribunda)

Rhododendron

(Rhododendron varieties)

Evergreen Shrubs

Japanese Yew

(Taxus cuspidata)

Juniper

(Juniperus varieties)

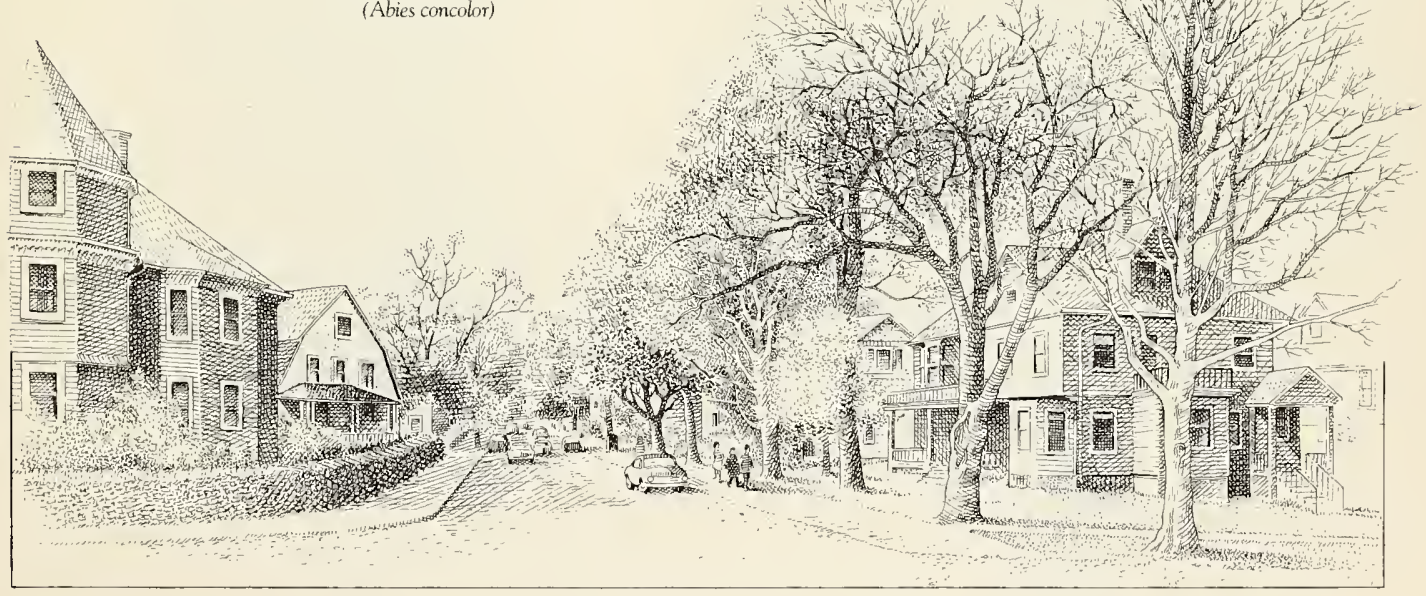




\section{Street Trees}

The following trees are recommended for planting on Boston's streets. They are selected because they are hardy in the Boston area; that is, they grow well under local conditions of temperature, rainfall, and soil. They tolerate the stresses of pollution, wind, and limited area for root development. Their shapes are strong and recognizable. At maturity they attain a height of fifry to sixty feet. They are reasonably resistant to insects and disease, and need minimum specialized care. Nurserymen and plant scientists are constantly developing new varieties of trees that respond well to the particular pressures of the city environment. The new varieties appropriate to Boston are included in this section.

A variety of trees should be planted on city streets. There is a very real danger in planting a limited number of species in a city because uncontrollable insect and disease attacks can demolish thousands of trees in a single species (Dutch elm disease is a sad and poignant example). Planting a variety of tree species on city streets prevents such disasters and also make a richer landscape.

Street trees are the backbone of a green city. They produce masses of green foliage in the summer, intense autumn color, and a lovely tracery of branches in the winter months.

Note: scale is $1 / 2^{\prime \prime}=5^{\prime}$

\section{Ginkgo}

\section{(Ginkgo biloba) Male Only}

One of the most beautiful and exotic trees for city planting. A native to China, the ginkgo is sometimes known as the maidenhair tree because of the similarity of its distinctive fan-shaped leaves to those of the maidenhair ferm. It is a wide-spreading, open-crowned tree with strong ascending branches that occasionally reach out beyond the general outline of foliage. The leaves turn a clear yellow in the autumn. It is almost totally resistant to attacks from insects and disease, and it survives moderate amounts of wind, soot, and other air pollutants. The female tree produces fruits with a very unpleasant odor, therefore only the male tree should be planted. The 'Sentry' variety, which is quite narrow and upright, is a recently developed form.

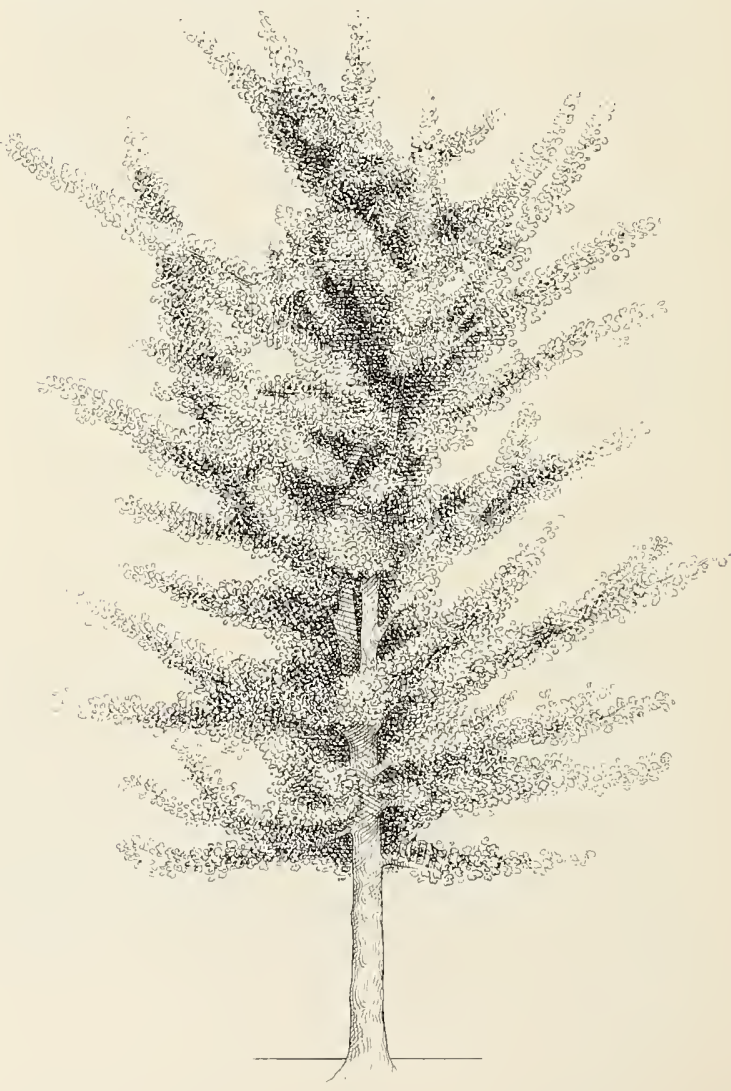




\section{Green Ash}

\section{(Fraximus pennsylvanica lanceolata)}

The green ash grows rapidly, is drought-resistant, and survives in relatively poor soils. It is pyramidal in shape, with glossy, dark green foliage that turns bright yellow in the autumn. Native to the eastern and central United States, the green ash has been growing wild in Boston along the banks of the Muddy River for many years. Because the female tree produces quantities of seed pods which litter city sidewalks and produce hundreds of chance seedlings, the variety 'Marshall's Seedless' is recommended for street planting.

\section{Katsura \\ (Cercidiphyllum japonicum)}

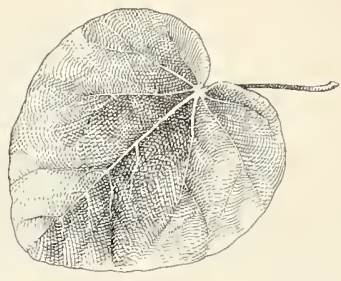

The katsura has distinct grace and delicate beauty. The heart-shaped leaves are rose-colored in the spring, blue-green in the summer, and yellow to scarlet in the autumn. When grown with a single trunk, the katsura makes an excellent street tree. It is generally vertical when young, becoming widespreading at maturity. Multitrunked specimens make excellent lawn trees. It is markedly resistant to pests and disease, but needs deep watering to survive. A native of Japan, the katsura is just now gaining popularity as a street tree in many eastern cities.

Little-leaf Linden (Tilia cordata)

The little-leaf linden is the great avenue tree of Europe. Equally successful in this country, the linden is planted extensively by architects and designers, who are attracted to the dense symmetry of its btanching pattern. The linden is oval-shaped, and has a strong and interesting winter silhouette. The dark, almost black bark is enhanced by heart-shaped, deep-green leaves that tum yellow-gold in the autumn. Linden flowers are produced in great numbers at the end of June and are very fragrant. Lindens do best in fertile soil and with ample moisture. The 'Greenspire' variety has a conspicuously nartow top, as opposed to the typical oval shape.

\section{London Plane \\ (Platanus acerifolia)}

The London plane has a strong, straight trunk with distinctive mottled gray to tan bark which exfoliates, or naturally peels off. The bark is a familiar sight to generations of city dwellers. The London plane is a natural hybrid between the American sycamore and the oriental plane tree. It grows rapidly, produces good shade, and is particularly hardy along the seashore. The London plane is susceptible to anthracnose, a disease which can disfigure the leaves; it can be controlled by spraying with a fungicide. A new variety, 'Bloodgood', which is resistant to anthracnose, has been developed and is just now being planted in Boston.
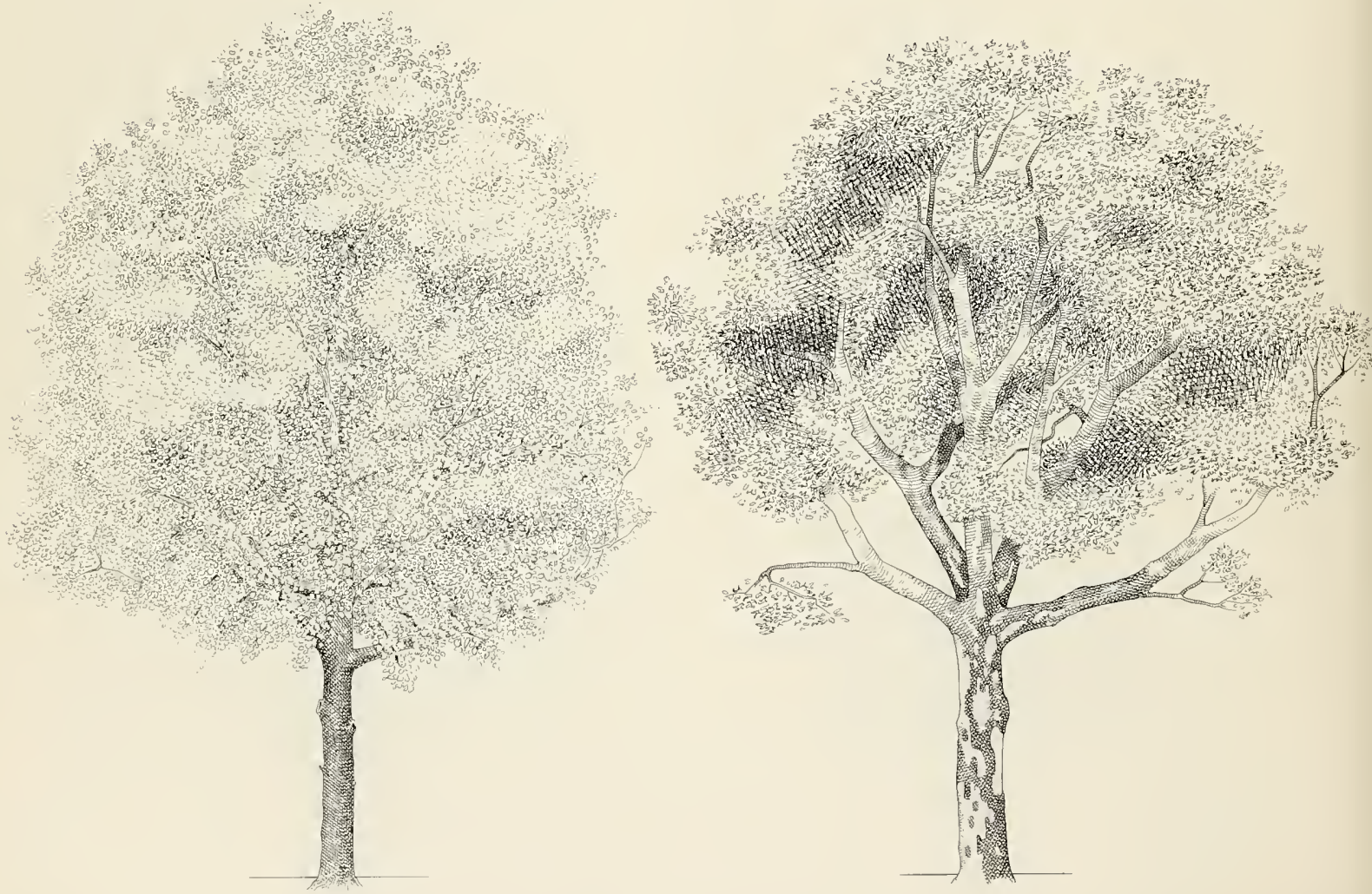


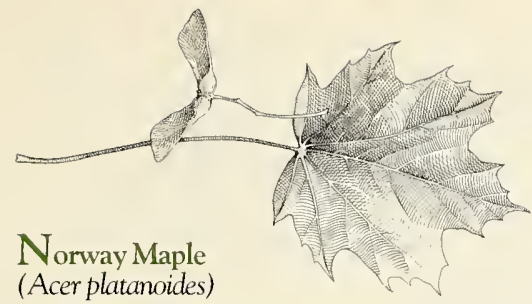

The Norway maple is fast-growing and tolerant of both persistent wind and moderate amounts of pollution. It is a popular and widely planted zree in Boston. It is, however, a shallow-rooted tree. Many of the feeder roots are very close to the surface, so the tree is susceptible to damage from compacting of the earth at its base and from salt used for de-icing. The base area of the tree should be protected. Several varieties of Norway maple are now being planted in Boston: 'Columnare', a dense and narrow form; 'Summershade', a heat-resistant variety; 'Swedleri', with red leaves in the spring that gradually rurn green in summer. 'Crimson King', with red leaves throughout the growing season, has heen widely planted in Boston but should be used sparingly as a specimen or accent tree.

\section{Pin Oak (Quercus palustris)}

The pin oak is easily recognized by its dense pyramidal branching pattern: the upper branches ascend to a narrow crown; the lower ones sweep almost to the ground. The deeply indented leaves tum a dark red in the auturnn. The pin oak is native to the United States and is used as a street tree in many cities, with lower branches pruned to prevent interference with traffic. The pin oak resists wind damage. It also survives the transplanting process better than most oaks. The variety 'Sovereign' is a new form with regularly upright branching.
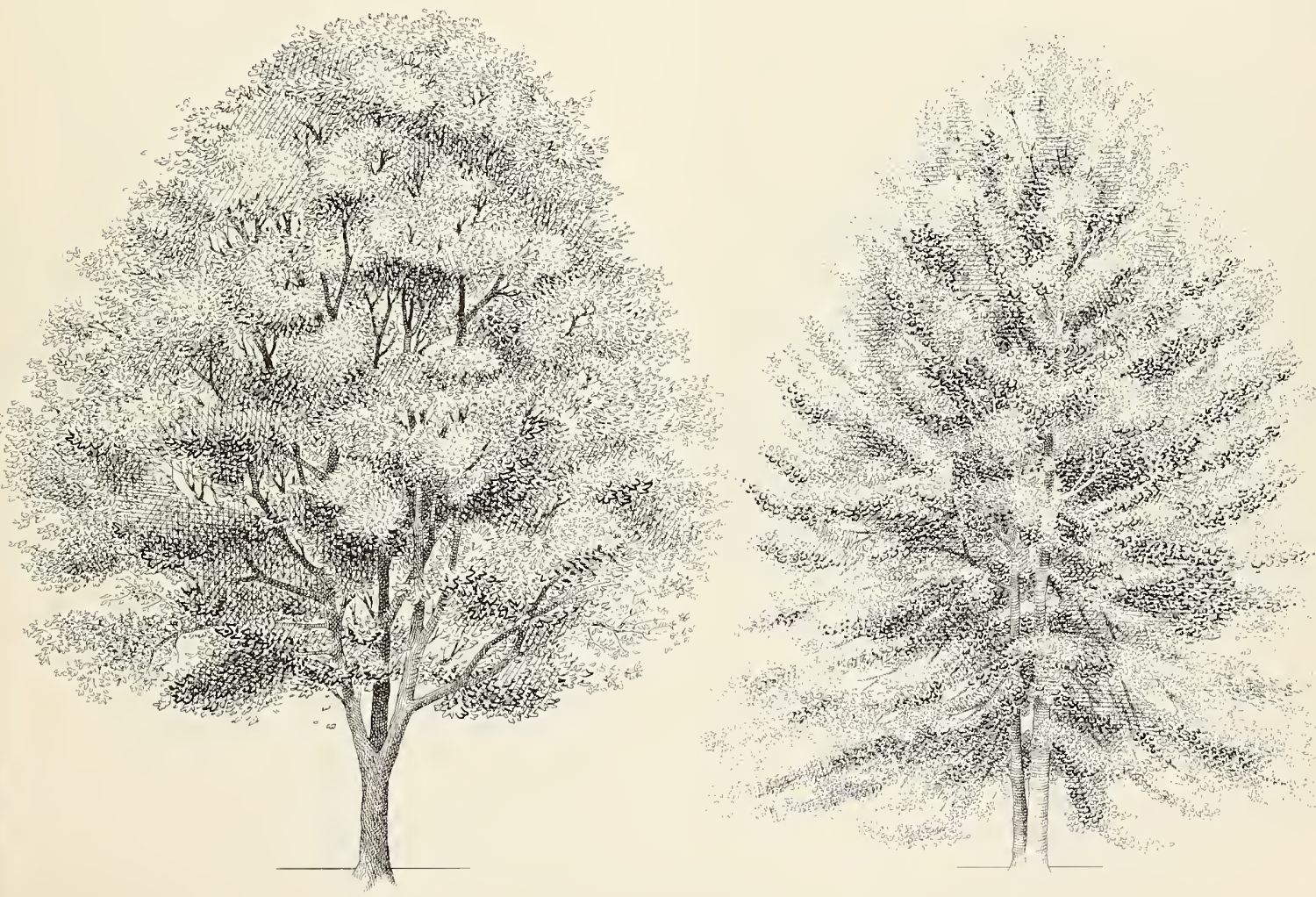
Red Oak

(Quercus borealis)

The red oak is native to New England. It is tough and dense, so it is an excellent shade tree for city streets. It is pyramidal while young, but slowly develops into a round tree. The glossy, pointed leaves turn a rich red in the autumn. It is not damaged by salt-laden air. The red oak was more widely planted years ago, but with the introduction of many new species to city streets this very worthy native tree has unfortunately gone out of fashion. Since it is tap-rooted, care must be taken to protect the root during planting. Once established, it grows rapidly and beautifully, making it well worth planting.

\section{Sweet Gum}

(Liquidambar styraciflua)

The sweet gum is an excellent tree for damp sites; in fact, it will not grow in dry areas. To ensure survival, it should be planted while still rather small. Symmetrical and pyramidal while young, it grows into a round shape when mature. The star-shaped leaves are a glossy, fresh green in summer and make a dazzling autumn display, with color ranging from bright orange to deep crimson. The fruits are hard and spiny and often stay on the tree throughout the winter. The ridged, corky bark exudes an aromatic sap.
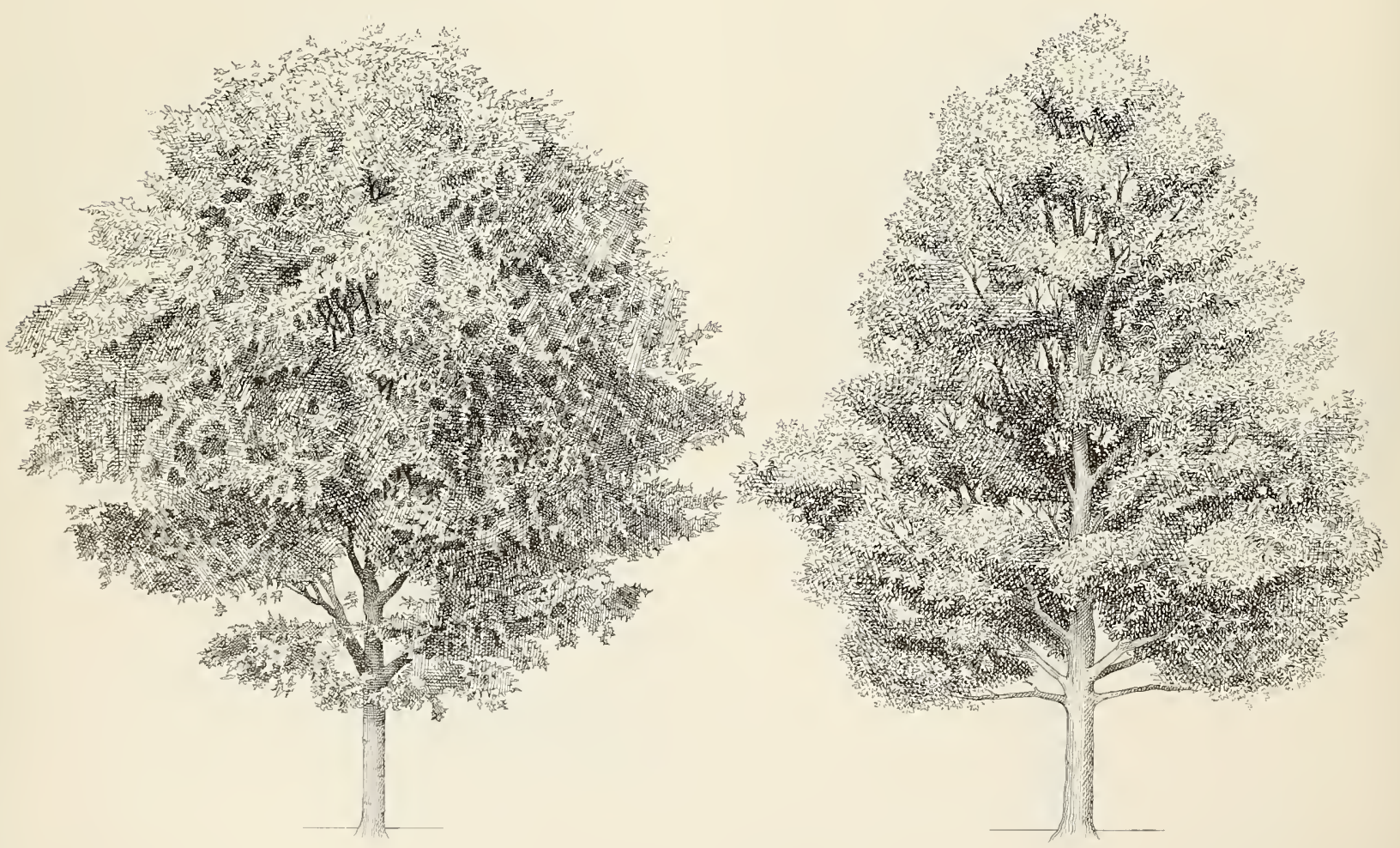


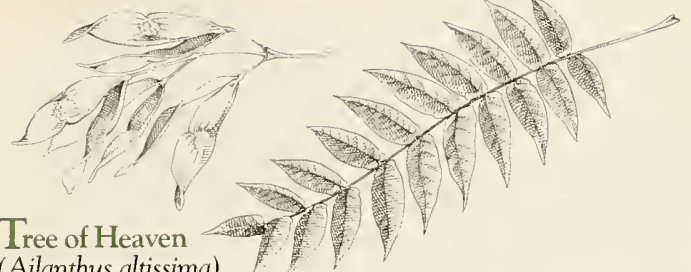

(Ailanthus altissima)

There are very few conditions in which an ailanthus will not grow. It will thrive in back allevs, empty lots, even sidewalk cracks. The ailanthus needs little nurturing to promote rapid growth, hence it is often called a weed tree. The tree deserves more respect, however, as its finely textured foliage, greenish-yellow flowers, and golden-red seed pods are a valuable addition to many urban spaces that are otherwise neglected. The ailanthus was brought to this country from England in the late eighteenth century. It is native to northern China, where it was used as silkworm food. Brought to the United States in the effort to establish a silk industry, it escaped cultivation and spread into urban areas, where it flourished. The ailanthus is not the kind of tree to purchase from a nursery, but is an interesting and valuable inhabitant of urban green spaces.
Japanese Zelkova (Zelkova serrata)

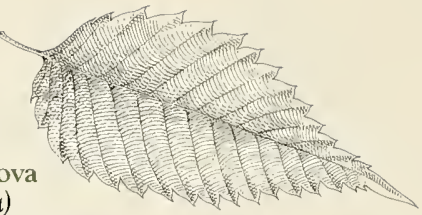

Cities hit hard by Dutch elm disease are now planting the zelkova as a substitute for the American elm. It has a shorter trunk and a more rounded crown than the classic vase-shaped elm. Its sharply serrated leaves turn a bronze-red in the autumn. Botanically speaking, the zelkova is a cousin of the elm, but is highly resistant to infection. The variety 'Village Green' is well suited to city streets, fast-growing, and transplants easily. The zelkova has been successfully grown in Boston; the best specimens are on the Commonwealth Avenue mall.
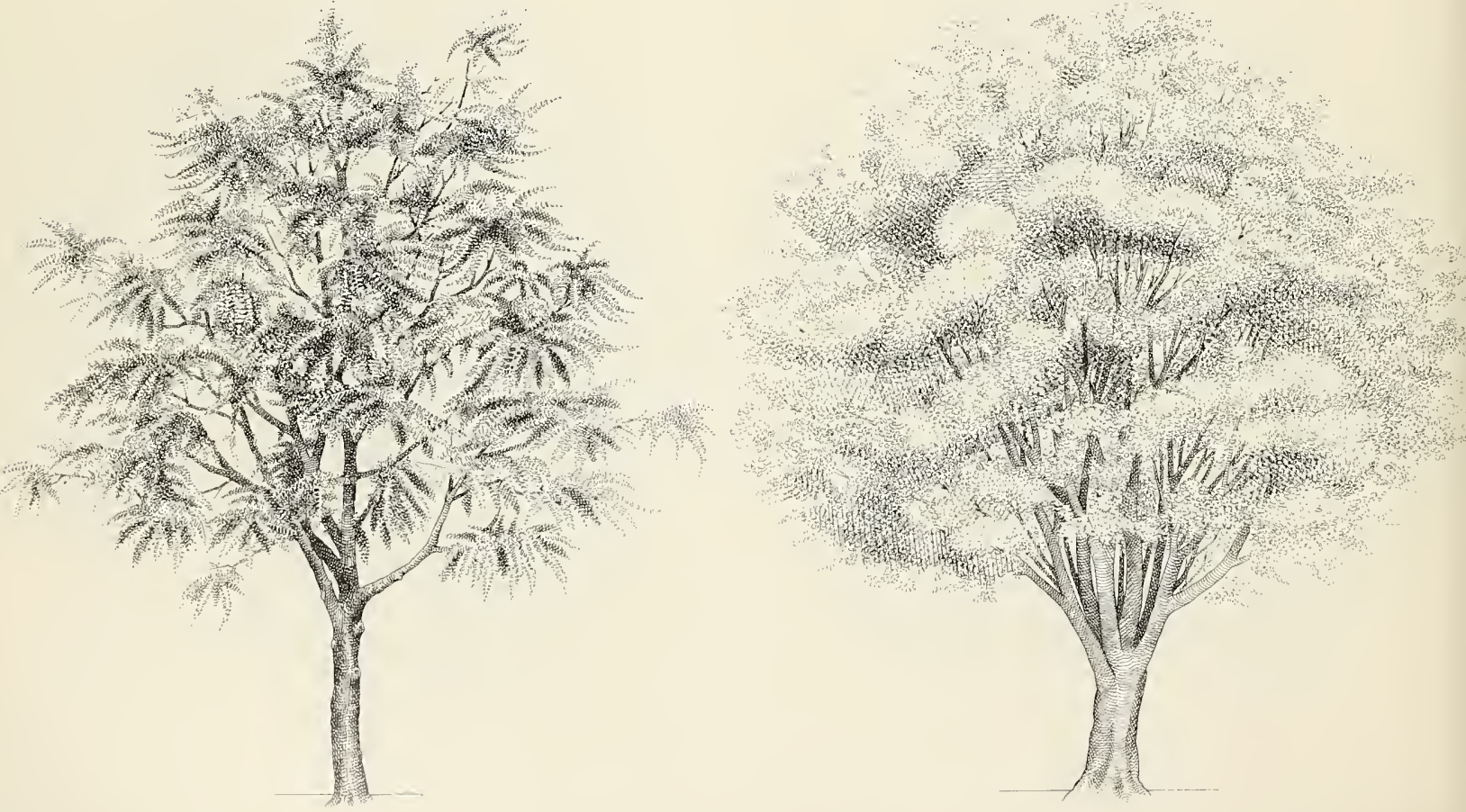


\section{Ornamental Trees}

Omamental trees are recommended for their outstanding seasonal displays of flowers and fruits. Whether planted singly or in groups, they add color, fragrance, and unique shape and texture to public spaces. Their mature height rarely exceeds thirty feet. Omamental trees are not usually suitable for street planting because of their widespreading, low-branching shapes, but are highly desirable in parks, front gardens, and other off-street locations.

Note: scale is $1^{\prime \prime}=5^{\prime}$

\section{Amur Maple (Acer ginnala)}

The amur maple does not flower but has great value as a small, spreading tree with spectacular autumn color. Rapid-growing, rounded, and shrub-like in habit, the amur maple will thrive in either sun or partial shade. It is tolerant of wind, and will grow in poor soil.

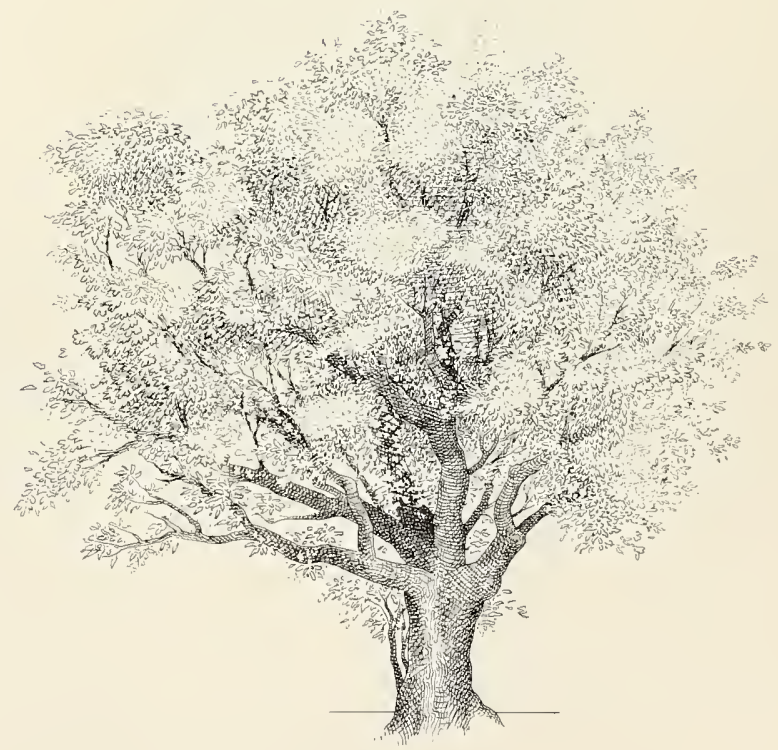




\section{Bradford Callery Pear (Pymus calleryana 'Bradford')}

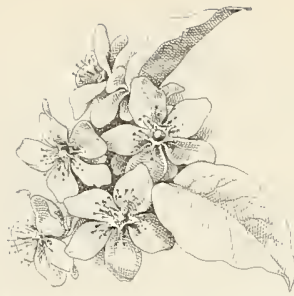

The dense pyramidal shape of the Bradford Callery pear makes it useful as hoth a street and an omamental tree. It was introduced by the United States Department of Agriculture in 1919 after a period of experimentation with seeds collected in China. White flowers appear in early May. The glossy green summer foliage turns deep red in the autumn. The fruits are quite small, less than an inch in diameter, and are consumed by birds while still on the tree.

\section{Cornelian Cherry (Comus mas)}

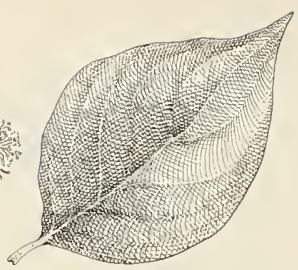

The comelian cherry is a member of the dogwood family and is native to southem Europe. Because of its multiple stems and low-branching patrem, it can be called either a small tree or a large shrub. The cornelian cherry flowers in late March or early Aptil; the abundant yellow flowers appear along the branches, just before the leaves unfurl. lt is sun-loving, insectand disease-resistant, and flourishes even in a windy site.
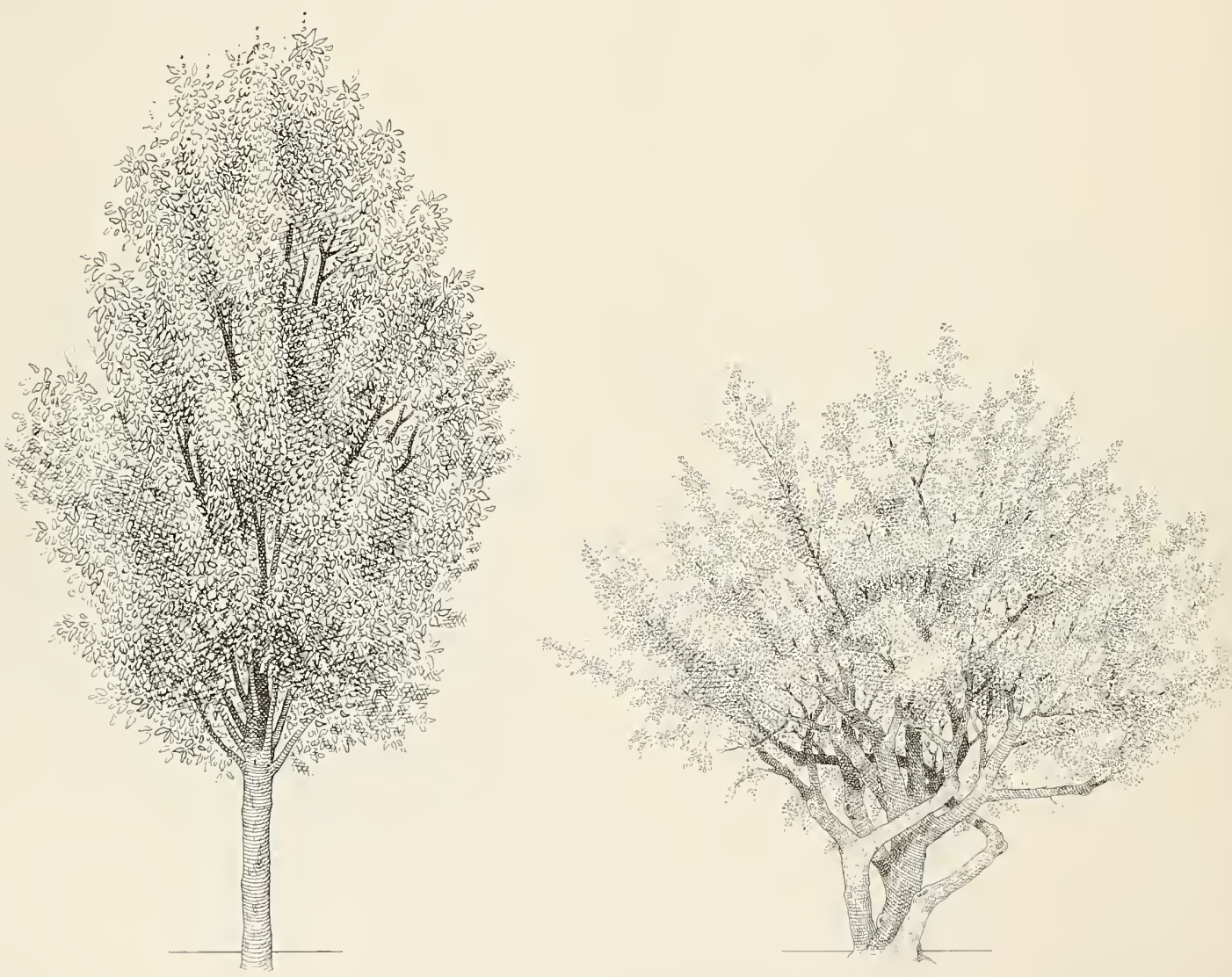


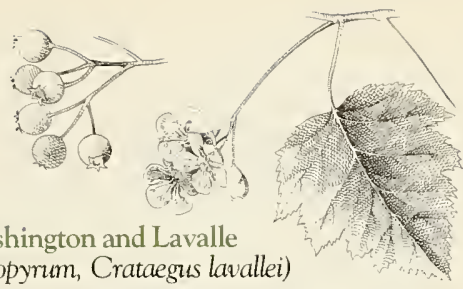

Hawthorns are excellent city plants. They have showy flowers and fruits and thrive in poor soils. They even do well in salt-laden air. However, many varieties are susceptible to fireblight, a serious disease. The Washing. ton and Lavalle varieties are both disease-resistant. The Washington hawthorn has white flowers in mid-June, orange fruits and brilliant scarlet foliage in the autumn. The Lavalle variety has white flowers and bright red fruits that stay on the tree well into the winter. Both varieties have thorns.

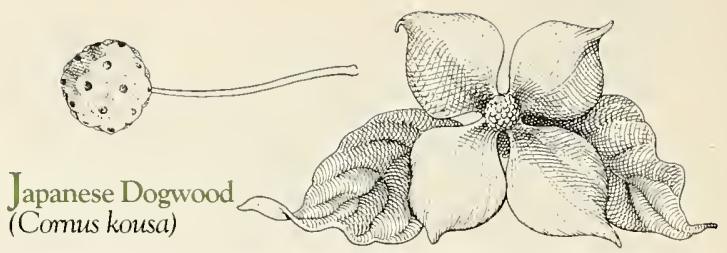

The Japanese dogwood blooms in mid-June, later than most other flowering trees. It is shrub-like, with many branches rising from the ground. The white flowers are profuse and long-lasting. The fruit, which is a strong feature of the tree, is large and bright red, resembling a large raspberry. Birds love it. The autumn color of the Japanese dogwood is bronze-red. The brown and white mottled hark is attractive in the winter.

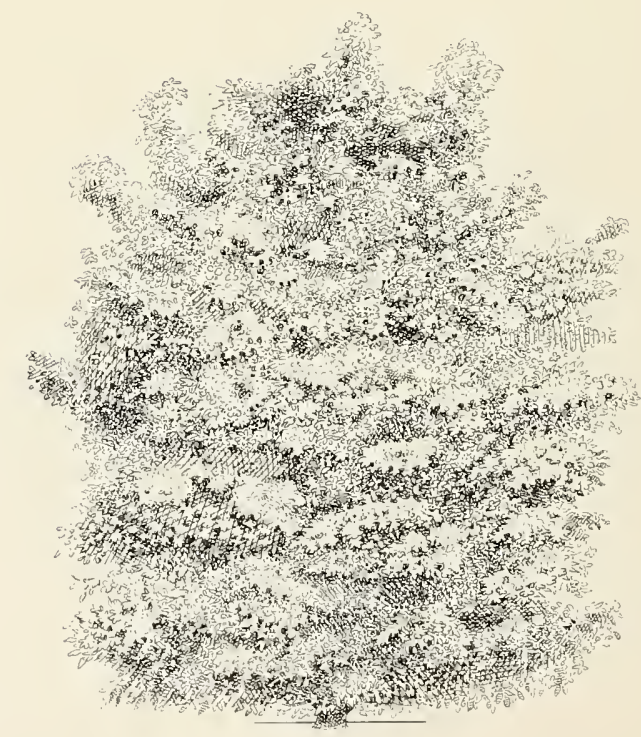


Magnolia, Saucer and Star

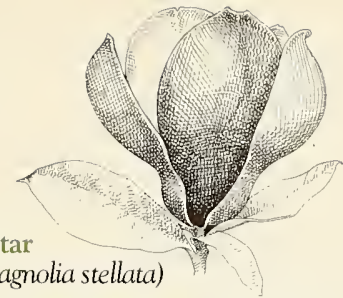

The flowering of magnolias in Boston's Back Bay is traditionally the first and one of the most impressive signs of spring. The magnolia is a widespreading, small tree which flowers best if it has some protection from the wind. The saucer magnolia (Magnolia sondangiana) has large, white, tulipshaped flowers which appear before the leaves and turn into small cucumber-shaped fruits in the fali. The star magnolia (Magnolia stellata) has fragrant, double-petaled white flowers. Both varieties are tolerant of air pollution.

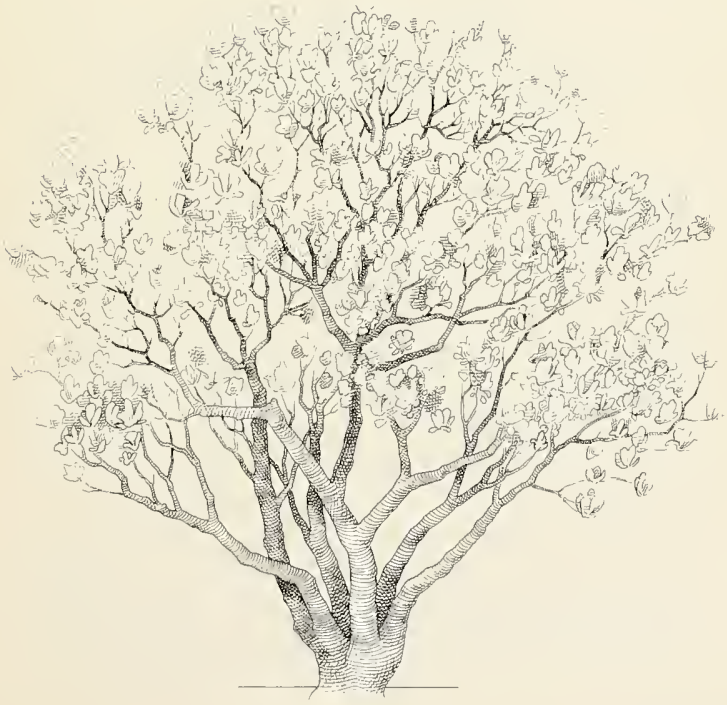




\section{Evergreen Trees}

\section{Austrian Pine \\ (Pinus nigra)}

One of the toughest evergreens for urban conditions. It is fast-growing and tolerant of poor soil, wind, and salt spray. It is a wide-spreading, flattopped tree with long, stiff needles. The Austrian pine is a dark and rather somber tree, but its usefulness as an evergreen screen and windbreak makes it a valuable tree for city conditions.

\section{Hemlock, Canadian and Carolina (Tsuga canadensis, Tsuga caroliniana)}

The hemlock is a very graceful tree with dense, dark-green needles and drooping branches. It needs moist, well-drained soil and good air circulation Both varieties are native to the United States. The Carolina variety is somewhat sofrer in appearance than the Canadian. Both varieties make good hedges, as the lower branches remain green and the whole plant can be sheared.

\section{Japanese Black Pine (Pinus thunbergii)}

Native to the coasts of Japan, this evergreen grows into an irregular and often picturesque shape. It thrives in wind and salt spray, and does best in dry, sandy soils.

\section{White Fir \\ (Abies concolor)}

The white fir is the only member of the fir family that will grow well in the city. It is a narrow tree with a pyramidal shape. The bluish-green needles make an interesting contrast with other plants. The white fir needs sun and well-drained soil.

\section{Deciduous Shrubs}

\section{Chinese Witch Hazel (Hamamelis mollis)}

This beautiful shrub, a native to central China, is one of the first plants to flower in Boston. Fragrant yellow and bronze flower clusters appear on the leafless branches in mid-March, often while snow is still on the ground. It grows into a wide-spreading shrub that needs only occasional pruning to keep ir compact.

\section{Cotoneaster, Rock and Spreading (Cotoneaster horizontalis, Cotoneaster divaricata)}

Cotoneasters are excellent shrubs for a variety of uses. Some varieties hold their leaves throughout the winter. Tiny white flowers in the spring are followed by a profusion of red berries that attract birds. Many varieties of cotoneaster are available. Rock cotoneaster is widely grown; it has flat horizontally spreading branches that grow no taller than three feet, and is an excellent ground cover. Cotoneaster divaricata grows upward to six feet with high arching branches. It can be trained to grow against a fence or a wall.

\section{Flowering Quince (Chaenomeles varieties)}

There are many varieties of quince available ro ciry gardeners. Quince blooms profusely in early May; the flower colors range from white to deep red. It flowers more profusely if regularly pruned, and can also make an excellent deciduous hedge. Flowering quince needs full sun and fertile soil. 'Nivalis', a white flowering variety, is particularly hardy. 'Cameo' has apricot flowers and distinctive bright green leaves, is low-growing, and is effective in mass planrings.

\section{Forsythia (Forsythia intermedia, Forsythia 'Amold Dwarf')}

Forsythia is probably the best-known flowering shrub in Boston. It is easy to grow, thrives in almost any type of soil, and has few insect pests and diseases. The bright yellow flowers appear in early April. Forsythia must be pruned regularly as it tends to become leggy. Pruning also increases its flowering. Intermedia varieries are the best of the tall-growing types. 'Amold Dwarf' is a low-growing variety that can be used as a ground cover.

\section{Japanese Green Barberry (Berberis thunbergii)}

One of the best shrubs for hedge planting in the city. Dense, thorny, tough, it grows in almost any soil and can withstand drought and pollution. It has small, yellow flowers in the spring, red berries in the fall. The fall color of the leaves is deep red. The variety atropurpurea has red leaves throughout the growing season

Lilac

\section{(Syringa varieties)}

The most valuable feature of the lilac is its beautiful, fragrant flowers. It has no autumn color and needs regular pruning to remove excess suckers and to promote new growth. It grows even more vigorously when lime is added to its soil. There are many varieties of lilacs to choose from, and many more are added to the nursery trade each year. Some are bushy; others develop like small trees. Flowers range in color from white to deep purple. If protected from excessive automobile pollution, lilacs do well in city gardens. The lilac collection at the Amold Arboretum is world-famous. There are hundreds of varieties which bloom throughout May and June.

\section{Rose of Sharon (Hibiscus syriacus)}

Rose of Sharon has been grown in this country since Colonial times. It is a distant member of the tropical hibiscus family, and is native to China and northern India. Sometimes known as shrub althea, it can grow into a sma!l tree if properly pruned. The most important feature of Rose of Sharon is its mid-surnmer blooming time, when few other shrubs are flowering. It needs 
good soil and adequate water. Both single- and double-flowered varieties are available. The color range is from white to deep purple.

\section{Scarlet Firethorn (Pyracantha coccinea)}

Pyracantha is an upright-growing shrub with dark bluish-green leaves. It is best grown against a fence or on a trellis. It has small white flowers in the spring, but is known for its spectacular orange berries, which appear in latge clusters in the autumn and are welcomed by birds. Pyracantha is susceptible to fireblight.

\section{Spirea \\ (Spiraea varieties)}

Over a hundred varieties of spirea grow in Boston's Amold Arboretum. Some are native to this country, and others have been brought from Europe and the Far East. Spireas are tough, hardy shrubs that need regular pruning to flower successfully. Bridalwreath spirea (Spiraea prunifolia) is an old. fashioned shrub and probably the most widely planted. It has small white flowers in mid-May, and red autumn color. 'Bumalda' is a low-growing variety with crimson flowers in late June and early July, and is particularly suited to small city spaces. The variety vanhouttei is a graceful, heavy-flowering plant that grows to a mature height of about six feet.

\section{Viburnum}

\section{(Viburmum varieties)}

Viburnums are an interesting group of plants; they range from large, sprawl ing, native varieties to more compact, heavy-flowering hybrids. Viburnums have dark, glossy leaves and white to pink flowers. Their profuse display of autumn fruit is highly attractive to city birds. The Mayflower viburnum (Viburnum carlesii) and the 'Doublefile' (Viburnum plicatum tomentosum) are highly valued for their flowers. Viburnum opulus 'Nanum' is a small, compact form that grows to a mature height of about two feet

\section{Broad-Leaved Evergreen Shrubs}

\section{Azaleas \\ (Rhododendron varieties)}

Azaleas are admired for their spectacular flower display in the spring. They have a rich history and are cultivated all over the world. Most varieties are deciduous in Boston. Azaleas need rich, acid soil and deep watering. A thick mulch over their root areas is essential. They will not survive in $\mathrm{dry}$, sandy soil. Most varieties thrive in light shade. Among the numerous types available, the Ghent, the Exbury and Knap Hill varieties are recommended for city planting.

\section{Inkberry}

\section{(Ilex glabra)}

Inkberry is native to the eastern United States, where it thrives in wet soils. While the flowers are not conspicuous, the small black fruits are profuse and attractive to birds. Inkberry has dark, lustrous foliage and makes an excellent backdrop for other shrubs.
Japanese Holly (Ilex crenata)

Japanese holly is a lovely and serviceable plant valued chiefly for its small, dark-green foliage. It can be grown as a single plant or as a border. It is a compact shrub with a fine, dense texrure. Several varieties are recommended for city planting: convexa, convexa compacta, helleri, and hetzi.

\section{Mountain Andromeda} (Pieris floribunda)

The upright white flower clusters of the mountain andromeda make a striking picture in late April. The flower buds are clearly evident on the plant throughout the winter. It is a compact plant, growing to a mature height of four to six feet. Mountain andromeda grows well in reasonably fertile soil. It has no serious insect or disease problems.

\section{Rhododendron (Rhododendron varieties)}

Rhododendrons and azaleas belong to the same plant family and need the same culture: acid soil and ample moisture. Rhododendrons are evergreen. Both small- and large-leaved types are availahle. The Wilson (Rhododendron laetivirens) is a small-leaved, compact plant with pink flowers. The white-flowered Carolina Rhododendron carolinianum album) has a beautiful display of flowers in mid-May. PJM and Catawba hyhrids are large-leaved types that do well in the city.

\section{Evergreen Shrubs}

\section{Japanese Yew (Taxus cuspidata)}

The Japanese yew is the most widely planted evergreen shrub in the ciry. It grows in semi-shade as well as full sun and withstands wind and pollution A single-trunked form (Taxus cuspidata capitata) grows into a large tree. The multitrunked shrub varieties form excellent hedges and screens. It is a dense, compact plant with dark-green needles. The female plant has red berries (which are poisonous) in the fall. All varieties can be sheared into fornal shapes.

\section{Juniper (Juniperus varieties)}

Junipers are a large group of evergreen plants that includes tree, shrub, and gtound-cover types. Because they withstand wind, drought, and poor soil, they are excellent choices for city planting. Foliage colors vary from bluishgrey to deep green among the many varieties. The chinensis varieties are particularly hardy and widely planted in Boston; columnaris, hetzii, pfitzeriana, sargentii are recommended. Of the many horizontadis varieties, 'Bar Harbor' and 'Plumosa' are particularly good in the ciry. 


\section{How to Plant and Care for Trees and Shrubs in the City}

\section{Planting}

\author{
When to Plant and Why
}

Planting is best done in early spring and late fall. Deciduous trees and shrubs should be planted when they are dormant, that is, before their leaves appear in the spring and after they drop in the autumn. Evergreen plants should be planted in the spring just before new growth appears, or any time be tween late September and late November. One should never plant trees or shrubs in the heat of mid-summer, when spring growth has exhausted the plant and its recuperative powers are low, nor should one plant in frozen ground. When possible, plant on a cool, cloudy day rather than on a hot, sunny one, as the sun can burn the tiny feeder roots necessary for new growth.

\section{How Trees and Shrubs are Obtained from the Nursery}

Bare-rooted plants are moved with all the soil removed from the roots. This is the least successful start for establishing city plants. Bare-rooted material requires very careful handling during the planting process, and often fails to survive.

Balled and burlapped plants are dug in the nursery field with a large ball of soil still surrounding their roots. The root ball is wrapped in burlap and tied with rope. Properly dug, the size of the root ball will be in proportion to the size of the tree. A good rule of thumb is that the root ball should be eight to ten times the diameter of the tree trunk as measured six to twelve inches above ground level. A tree with a trunk of four inches will have a root ball thirty-two to forty inches across.

Containerized plants are grown in the nursery in metal or plastic containers. The advantage of containerized plants is that they do not need to be planted immediately after purchase, as long as their soil is kept moist. Since containerized plants suffer much less transplant shock they can be planted well into June. Plants should be removed from containers before planting.

However they may be packaged, plants should be purchased from professionally managed, reputable nurseries. Plants dug in the wild might survive in rural or suburban areas, but will experience great difficulty adjusting to city conditions. In selecting plants at a nursery, one should look for healthy, unscarred bark, full buds, and a welldeveloped shape. The ends of the branches should be flexible and green, not brittle and dry. The root ball should be firm and unbroken.

\section{How Big}

Shade trees such as maples, oaks, and lindens should have caliper measurements of at least two to four inches. The caliper is the diameter of the trunk of the tree when measured about six to twelve inches above ground level. Flowering trees are usually measured by height rather than by calipera height of six to ten feet is ideal. Any street tree smaller than two inches in caliper needs special protection if it is to survive. Trees larger than four inches in caliper cannot be moved without machinery and are best planted by professionals.

\section{City Soils}

City soils are generally of poor quality. They often lack organic material, are mixed with stones and rubble, and require the addition of new topsoil during the planting process. The basic procedure for any size urban area - even a single planting holeis to provide as much good-quality topsoil or loam as possible. The more topsoil one gives to newly planted trees and shrubs, the better their chances for survival will be.

\section{Planting Hole}

The hole should be deep enough and wide enough to hold the full root structure of the plant and a layer of topsoil both beneath and around it. This can be accomplished by digging a hole one foot larger in diameter than the spread of the root system, and six inches deeper than its depth. Trees and shrubs should be planted at exactly the ground level at which they were formerly growing. If set too deep, the surface roots may suffocate; if set too shallow, these roots will be too close to the surface and may dry out. The planting hole should be roughly square at the bottom, to allow the plant to be set in securely and to prevent air pockets after back-filling. Six inches of topsoil should be placed at the bottom of the hole before the plant is set into it. Slowacting organic material such as dried manure, cottonseed or bone meal, or compost can be mixed with the topsoil as plant food, but commercial chemical fertilizers should not be used at planting time. Topsoil, manure, and cottonseed and bone meal can be purchased in small quantities from nurseries and garden centers. Larger quantities are available from commercial suppliers.

\section{Putting the Plant into the Ground}

Set the tree or shrub at the proper level in the planting hole. The trunk should be as upright as possible. If the plant is barerooted, spread the roots out evenly and keep them moist. If balled and burlapped, the rope holding the burlap should be cut and loosened, and the burlap pulled slightly away from the side of the plant. Do not remove the burlap, however, as the entire root ball might be seriously disturbed; the burlap will gradually decompose after planting. If the plant is containerized, remove it by cutting away the container. After setting the plant, start filling the hole with good soil. Carefully work the soil around and under the roots to eliminate air pockets. As the hole is filled, tamp the soil layers lightly with your foot. When the new soil has reached the level of the existing soil, tamp it more firmly. Build up a ring of earth around the edge of the planting hole to prevent water from running off before it soaks down to the complete root area. This "saucer" is extremely important to city plants, which often have limited growing space and consequently little access to ground water. Trees and shrubs should be thoroughly watered immediately after plant- 
ing. Follow-up watering is especially important in the first few months to prevent wilting. It is good practice to prune a tree lightly after planting. This compensates for root loss during the transplanting process, by keeping the evaporation of water through the leaves in balance with water intake through the roots.

\section{Staking, Guying and Wrapping}

Roots hold older, established trees in place, but the newly planted tree needs artificial support for the first year or two when it is less stable. Staking or guying is necessary to stabilize the young tree and keep its new root growth from being broken off by constant shifting of the root ball because of wind. One stake is generally sufficient for a tree that is under three inches in caliper; two stakes are necessary for larger trees and all trees in very windy locations. Stakes may be of any durable, knot-free wood (clear cedar or spruce are often used), and should be at least one-and-one-half inches square. They can be stained or painted; black or brown colors are better than green, as they more closely resemble the color of the tree trunk. Metal stakes or pipe can also be used. Stakes should be driven into the ground at least one foot outside the planting hole, so the roots will not be damaged. The stakes should extend to the lowermost branches of the tree and be attached to the trunk with galvanized iron wire. A piece of old garden hose or several layers of burlap should enclose the wire where it encircles the tree, to prevent the bark from being cut and scarred. The wire should be loosened after the first year to prevent choling of the tree. After two growing seasons, when the new roots are firmly established, the entire staking apparatus can be removed.

The trunks of newly planted trees are often wrapped to prevent sun scald and evaporation of moisture through the bark. A heavy, double-layered paper is made for this purpose and is available in hardware stores and garden centers. Strips of burlap, cut four to six inches wide, can also be used as wrapping. The tree trunk should be wrapped from the base to the first major branches in an overlapping fashion, much like a bandage.

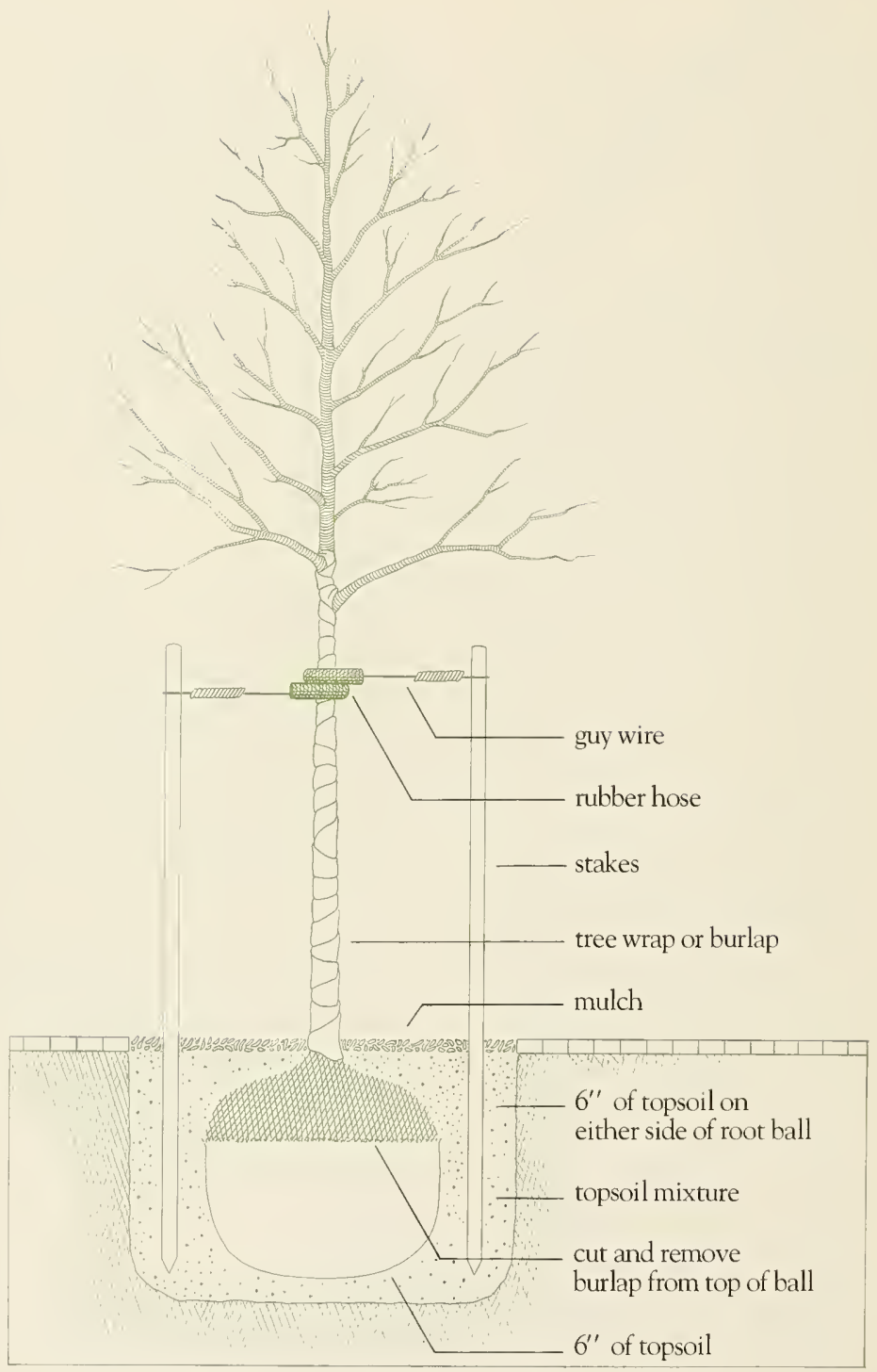


The wrapping should remain on the tree for no longer than one growing season. Insects, particularly borers, sometimes find their way under the tree wrap and damage the trunk. In addition, the wrapping will restrict the tree's growth if left on too long.

\section{Mulching}

Immediately after staking the tree, a layer of mulch should be placed around its base. Mulch holds in soil moisture, prevents compacting of soil, and restricts the growth of weeds. Mulching materials should be heavy enough to resist being blown or washed away. Bark mulch is excellent; the finely shredded type is better than the large nuggets, as it takes less to make a dense layer. Wood chips are also good. Mulch should initially be laid down at a depth of three inches. It should be checked each spring and added to if the depth has lessened.

\section{Protecting the Tree-Pit Area}

Mulch is sufficient protection for trees planted in front gardens, backyards, and raised planters. But street trees often need additional protection from soil compaction, dogs, and weed growth. The choice of a method for finishing off a tree-pit area depends on the amount of pedestrian traffic on the street. An excellent choice for very busy pedestrian areas is a metal tree gate, which covers the root area but allows moisture to pass through. Metal grates on public sidewalks must be ordered and installed with assistance from the city. Other choices are suitable to quieter streets, are less expensive, and can be constructed by residents or civic groups. Cobblestones or bricks set in sand are functional and very attractive, but one must be sure that these paving materials are set loosely and far enough apart to allow sufficient water to seep down to the root system. The degree of soil compaction should be checked every few years. Another tree-pit design, seen in many Boston neighborhoods, uses brick or stone edging around a planting of small bulbs, annuals, or ground cover at the base of the tree. This prevents the soil around the tree from being compacted by pedestrians. The flowers also add color to the street.
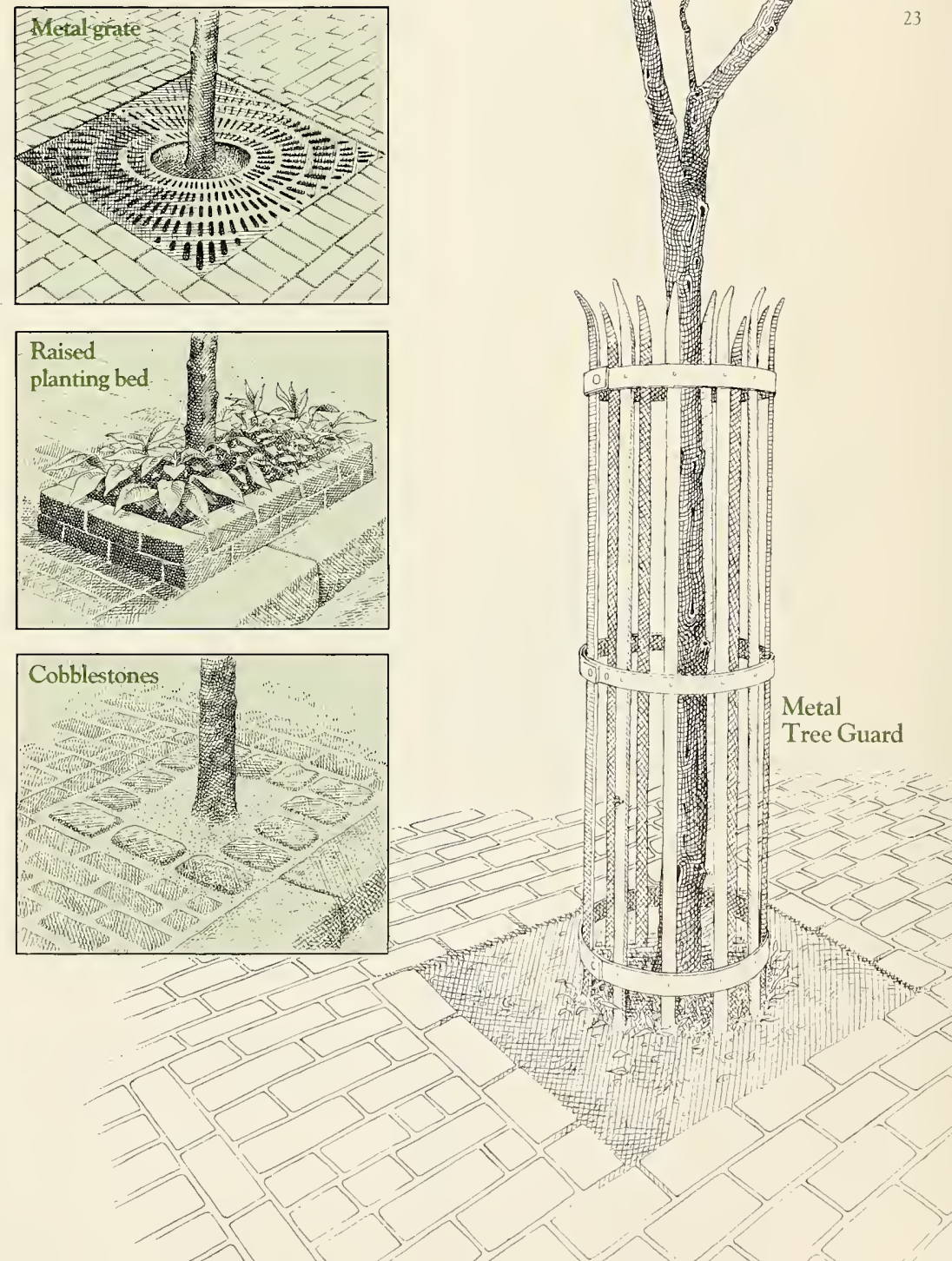


\section{Tree Guards}

Tree guards are excellent devices for protecting street trees in busy traffic areas. They detour pedestrians around the root area and protect the trunk from injury by cars and trucks. They also keep dogs from getting too close to the trees. These guards are made in many styles and sizes by ornamentaliron workers.

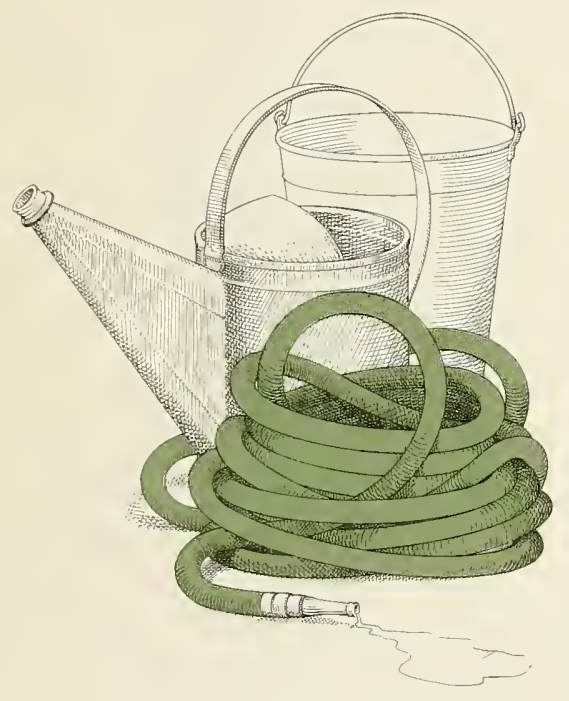

Caring for

\section{Trees and Shrubs in the City}

\section{Watering}

Water is the most critical factor in the survival of any plant in the city. Water must soak into the ground slowly to be accessible to all the feeder roots of the plants. Repeated shallow watering can be harmful to trees because it forces them to develop root systems too close to the surface. Surface roots do a poor job of anchoring the tree, and are always more vulnerable to injury than the deeper roots. If an ordinary garden hose is used, the nozzle should be removed and the water pressure kept fairly low; the hose should be laid at the base of the tree for at least a half-hour, or until the ground has absorbed what it can. If a garden hose is not available, an ordinary pail can do the job. Established street trees need at least ten gallons of water a week, including rainfall; newly planted trees need more, especially during hot and dry weather. The leaves should be sprayed occasionally with a hose to remove dust and soot. This should be done on a cool, cloudy day or in the evening, so the natural respiration of the leaves in sunlight is not affected. Extremes in watering should be avoided. Too little water causes roots to dry up and die, while too much water drives the oxygen out of the soil and causes roots to decay.

\section{Winter Protection}

Evergreen plants lose moisture to the dry, cold winter winds and are left with dead leaves or needles in the spring. Excessive water loss can be partly offset by spraying the needles or leaves with an anti-desiccant The most widely used type is a liquid plastic, which is diluted in water and sprayed onto the foliage in the late fall. It coats the leaves and prevents moisture loss. Anti-desiccants can also be used on deciduous plants to help prevent wilt during transplanting.

\section{Fertilizing}

In the forest, leaves and dead branches fall to the ground, decay, and return nutrients to the soil. This does not happen along city streets; street soils receive little or no continuous enrichment. When nutrients are needed by the city tree, they must be provided. But this must be done with knowledge of the tree's nutritional requirements. Nitrogen, phosphorus, and potassium are essential for plant growth and are the main ingredients of commercial fertilizers. High nitrogen fertilizers are best for trees and shrubs, and therefore a mix labeled $10-8-4$ or $10-6-4$ is recommended. The first number in the series represents the relative percentage of nitrogen; the second, of phosphorus; and the third, of potassium. Fertilizer can be purchased in either liquid or dry powder form. The liquid type, further diluted with water, is the easiest method for city dwellers to use as it can be poured around the plant and watered in. Dry fertilizer is usually applied by punching holes in the soil surrounding the tree, filling the holes with fertilizer, and then covering it with soil. The whole area is then watered to dissolve the minerals and carry them to the roots. Both liquid and dry fertilizer should always be kept at least one foot away from the trunk to prevent burning. It is important to follow the manufacturer's instructions carefully because over-fertilizing can permanently damage plants. Some trees never need fertilizers. If healthy new growth appears every year and the tree looks to be in good condition, it is getting enough nutrients from the soil. But if a tree or shrub appears weak and new growth is sparse, an application of fertilizer every two or three years at the most may be necessary. Trees that have been physically injured or hit by disease tend to recover more quickly if fertilized. One should fertilize plants in the early spring before new growth begins, or in the late fall when the possibility of new growth is past-but never in mid- to late summer. 


\section{Pruning}

There are many important pruning jobs that can be undertaken by city residents to prolong or save the life of a tree. However, pruning a large tree isn't an easy task. Heavy branches that are damaged, diseased, or dead should be removed by professional arborists or landscape contractors, who know the proper techniques and have the right equipment.

\section{When to Prune}

Shade trees are most successfully pruned in the early spring, when they have a whole growing season over which to heal. They can also be pruned in the late fall when dormant. The following rules are important when pruning flowering trees and shrubs. Plants such as dogwoods, crab apples, magnolias, and forsythia that bloom in the early spring set their flower buds during the previous summer. They should be pruned after they have flowered. Late-flowering shrubs such as Rose of Sharon bloom on the new season's growth and should be pruned in the late winter or early spring before the new growth starts.

\section{Pruning Tools}

Expensive equipment is not necessary for small pruning jobs. A pruning saw, a small pair of pruning shears, and a can of tree paint (available at most hardware stores and garden centers) should suffice for handling most problems. A carpenter's saw should not be used, as the teeth are too fine and the saw will bend in live wood. Tools should be cleaned after use, or disinfected with alcohol, because plant diseases are often spread through pruning tools.

\section{What to Prune}

1. Dead, broken, and diseased branches should be removed to prevent decayproducing fungi from penetrating the tree.

2. Young, single-trunked trees should have competing trunks, or "leaders," removed. It is important to know the mature form of the plant before pruning, but generally speaking, all street trees should be grown with a single trunk or leader.
3. All suckers (fast-growing sprouts which appear at the base of the tree) should be cut out. They tend to spoil the appearance of the tree, and use some of the water and nutrients that are needed by the principal part of the tree.

4. Branches that interfere with pedestrian and street traffic should be pruned back. Large street trees should have their bottom branches removed when they threaten pedestrian safety and obstruct drivers' views.

5. Shrubs can be rejuvenated by selective removal of old wood, especially at the base. This stimulates new growth and better flowering. Certain shrubs such as forsythia and spirea, which grow both tall and leggy, can withstand strong pruning, almost to the ground. They will return with vigorous and denser growth.

6. Girdling roots are often a problem with street trees, and should be removed. When root grow th encounters compacted soil or pavement, it moves back toward and around the trunk, girdling the base. Girdling roots are often seen growing above the soil surface. They should be cut off close to the trunk with a sharp wood chisel. The exposed root end should be treated with tree paint.

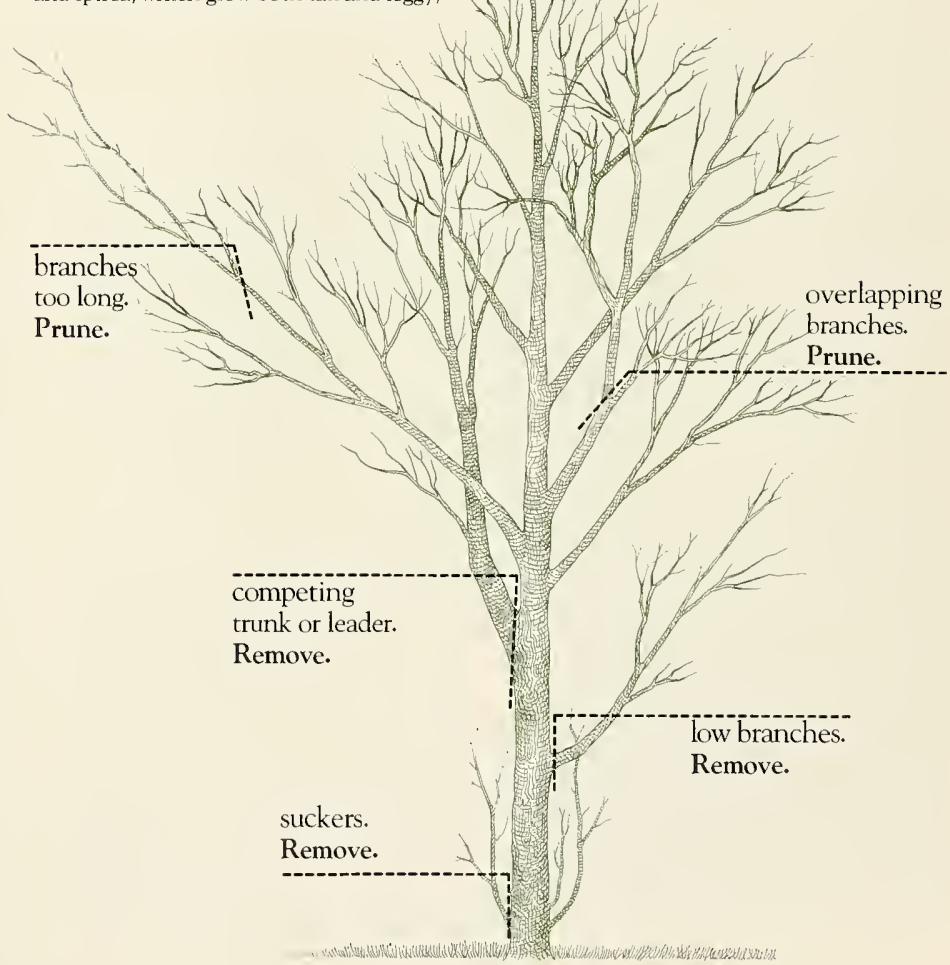



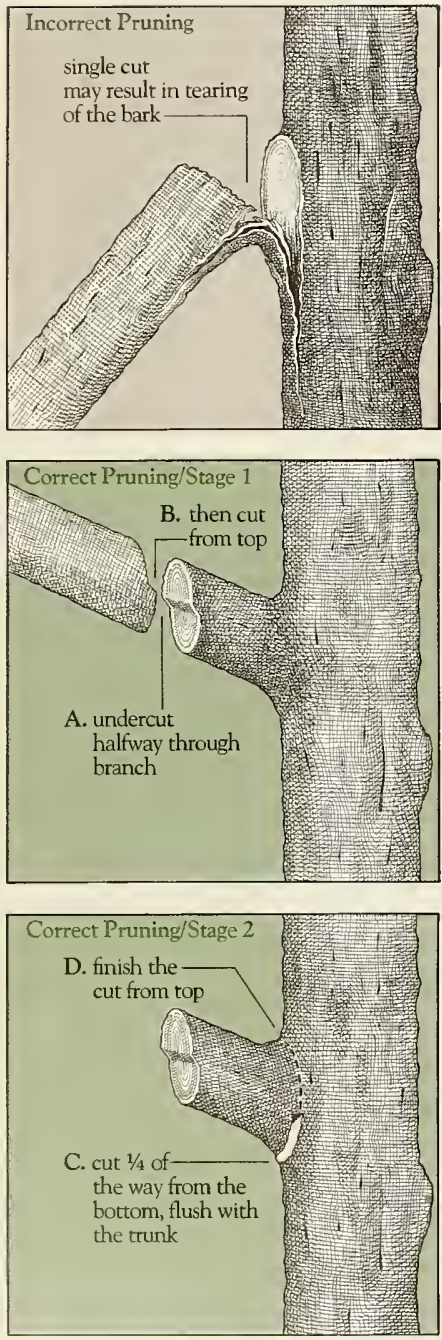

\section{How to Prune}

Lopping off a large branch with a single saw-cut often results in badly torn bark, which gives entrance to insects and disease. It is important to cut a branch back to about a foot from the final cut and then remove the stub with a second, double cut. The final cut should be close to the trunk or to the larger branch, so the cut will heal and prevent insects and disease from entering the tree. The final cut should be coated with tree paint.

\section{Treating Wounds}

Street trees are often gouged by cars and trucks, and damaged by vandals. If major wounds are not treated they become entrances for insects and disease into the living substance of the tree. The bark edges of the damaged area should be cut back in the shape of an elongated egg, with the points following the flow of sap. The exposed wood should then be painted over with tree paint (not house paint, which can damage the tree). The elliptical cut should be shaped so that water will not stand in the wound. Large wounds usually need repainting once a year or until they are completely healed. When tree wounds are not treated, the wound area may decay and develop into large cavities. Repairing large cavities is a complicated procedure; it should be done by an experienced tree surgeon.

\section{Insects}

There are three classes of destructive insects: chewing insects, sucking insects, and borers. Chewing insects such as tent caterpillars, coddling moths, and leafminers actually eat plant tissues, usually the leaves. Sucking insects such as aphids, spider mites, and mealy bugs appear in great numbers to suck the juices from leaves, flowers, fruit, and sometimes small branches. Borers are the most troublesome insects that attack city trees, as they eat their way through the woody parts of the tree, including the roots, and leave networks of tunnels. These in turn become homes for wood-rotting fungi and other insects; the borings also weaken the structure of the tree. Once borers have in- fested a tree, eliminating them is complicated. Their tunnels must be located, toxic paste injected, and the tunnels sealed. Safe insecticides are the only solution for attacks that menace large groups of trees or threaten the life of a single plant.

\section{Diseases}

Plant diseases are caused by bacteria, fungi, and viruses. Bacteria are one-celled organisms that spread quickly and interrupt normal processes of growth. Fungi interfere with the nourishment system of the living parts of plants. Viruses, which are often associated with insects, are responsible for some of the most serious plant diseases and are the most difficult to counter.

\section{Common Diseases of City Trees and Shrubs}

1. Verticillium wilt is a disease that clogs the sap-conducting vessels of a tree. Caused by a fungus, it first shows up as a sudden wilting of leaves on a single branch. The affected part should be removed as soon as possible, before the fungus infects other parts of the tree. Norway maples are most commonly affected.

2. Dutch elm disease is the devastating disease that has destroyed thousands of American elms. It is caused by a fungus carried through the tree by the elm bark beetle. The tree is generally infected in the spring; by mid-summer, whole branches may suddenly wilt and drop their leaves. All diseased parts of the tree should be removed. But Dutch elm disease is highly contagious, and there is no certain cure for a tree that is seriously infected. The most successful preventative is Lignasan, a chemical compound that is injected into the base of the tree. Lignasan has proved successful in the last few years in preventing the spread of this disease, and many magnificent old trees have been saved. The American elm is the most susceptible, but Chinese and English elms are sometimes affected. Several diseaseresistant varieties of elm have been developed; none of them have the distinctive vase shape of the American elms, but they are nonetheless valuable shade trees. The 
varieties 'Christine Buisman' and 'Groenveldt' have done well in Boston thus far.

\section{Fireblight is well known to fruit-tree} growers as a serious disease of apple and pear trees. It also attacks ornamental plants: hawthorn, cotoneaster, and pyracantha.

When attacked, leaves and flowers wilt, turn black, and look as if they have been scorched by fire. If unchecked, fireblight seriously disfigures trees and shrubs. Control is accomplished by pruning off the diseased parts and, if the disease is serious, by spraying with a fungicide.

4. Powdery mildew often affects lilacs and to a lesser extent oaks and London plane trees. Powdery mildew usually occurs near the end of the summer. It is more common on trees and shrubs growing in damp and shaded areas. It generally does little serious damage; leaves and twigs become covered with an unsightly grayish-white powder. It can be controlled somewhat by raking up all affected leaves in the fall and destroying them.

5. Anthracnose is caused by several kinds of fungi. The symptoms include brownish spots on the leaves and occasionally small cankers on the twigs. In serious cases, the tree can become defoliated by mid-summer. The London plane tree is very susceptible, but maples, elms, and dogwoods can also be hit. Healthy trees usually recover from a single attack, but repeated defoliations will eventually weaken them. Spraying with a fungicide is the only permanent remedy.

\section{Drought}

A prolonged drought causes the tree's or shrub's root hairs to collapse, and eventually the whole plant will die. Intermediate symptoms generally will be wilting and yellowing of the leaves. Drought damages young or newly planted trees more seriously. If remedied in time by regular, deep watering, the chances for plants surviving even the most serious drought are good.

\section{Urine Scald}

Dog urine contains high concentrations of salts that burn both bark and roots. Dog droppings, which decompose and become part of the soil, are also harmful to roots. Metal or wire collars placed at the base of trees protect the bark against dog urine. Raised guards around the tree pit prevent dogs from approaching the base of the tree. Dogs nonetheless are part of city life. They can be prevented from damaging city plants, but this depends on the sensitivity and consideration of their owners.

\section{Salt Damage}

Heavy amounts of salt used for snow removal, when left near the base of trees and shrubs, burn the feeder roots and cause stunted plant growth. If this occurs over many seasons it can kill the plants. The only remedy is to prevent salt from entering the tree-pit areas. Homeowners can use sand or a commercial salt substitute for de-icing sidewalks. If salt has been deposited by others, the tree or shrub should be heavily watered as soon as the weather is warm enough for the soil to accept water. Watering leaches the salt downward and away from the roots. Salt spray thrown up by cars and trucks can coat twigs and branches; a good spraying with water in the early spring is helpful in removing it before new growth is damaged.

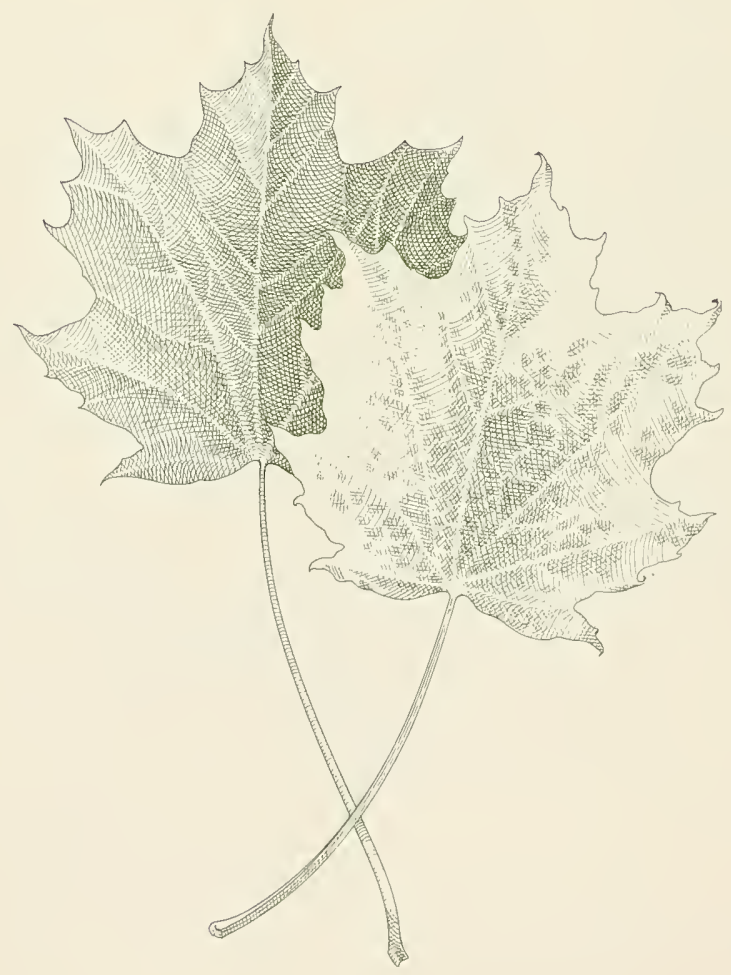




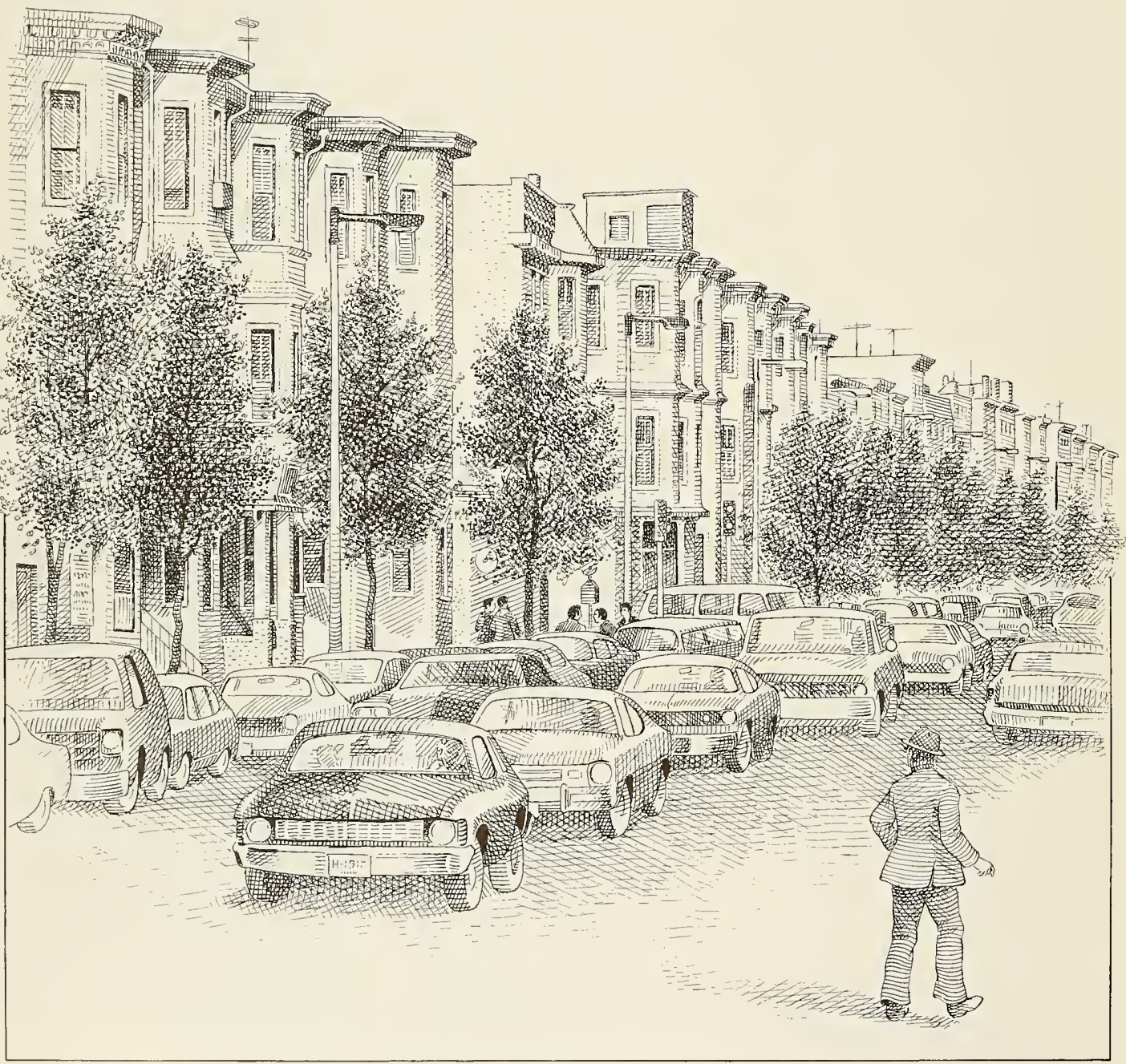

Cheluea Street, East Bostmi 


\section{Collections of Trees and Shrubs in the Boston Area Open to the Public}

\author{
The Arnold Arboretum. \\ The Arborway \\ lamaica Plain, Massachusetts
}

265 acres with some 6,000 varieties of labelled trees and shrubs. Open to pedestrians sunrise to sunset every day of the year. No admission charge.

\section{Boston Public Garden}

The first public botanic garden in the United States. Established in 1893. Almost 100 different varieties of deciduous trees. Many mature specimens. Labelled with name and country of origin.

\section{Case Estates of the}

Arnold Arboretum

135 Wellesley Street

Weston, Massachusetts

Experimental garden. 112 acres. Self-guiding tours. Display area for small trees suitable for city planting. Open mid-A pril through September 9:00 am to $6: 00 \mathrm{pm}$. No admission charge.

\section{Garden in the Woods}

Hemenway Road

Framingham, Massachusetts

Largest collection in the northeast of native plants growing in natural surroundings. 43 acres. Monday through Saturday 8:30 am to $5 \mathrm{pm}$. Admission charge.

\section{Mount Auburn Cemetery \\ 580 Mount Auburn Street}

Cambridge, Massachusetts

Garden cemetery with an arboretum of labelled specimen trees. 164 acres. Daily $8: 00$ am to $7: 00 \mathrm{pm}$. Winter to sunset. No admission charge.

\section{Books and Articles on Trees and Shrubs in the City}

Brooklyn Botanic Garden Handbook Series. These low-cost booklets cover many aspects of gardening and horticulture. The following titles are of particular interest to city gardeners.

Handbook on Soils

One Hundred Finest Trees and

Shrubs for Temperate Climates

Gardening in Containers

Pruning Handbook

Garden Pests

Flowering Trees

Flowering Shrubs

Crockett, James Underwood. Trees. New York: Time-Life Books, 1972.

Elias, Thomas S. and Howard S. Irwin.

"Urban Trees," Scientific American, November 1976, pp. 111-118.

"Edwards, Joan. Caring for Trees on City Streets. New York: Scribners, 1975.

Foster, Ruth. "Roots: Caring for City Trees," Technology Review, July/August 1977, pp. $29-35$.

*Gallob, Edward. City Leaves City Trees. New York: Scribners, 1972.

Johnson, Hugh. The International Book of Trees. New York: Simon and Schuster, 1973.

Page, Nancy M. "A Guide to Selecting a Strong and Healthy Young Tree," Amoldia, September/October 1973, pp. 261 - 283

Page, Nancy M. and Richard E. Weaver Jr. Wild Plants in the City. New York:

Quadrangle, 1975.

Pirone, P.P. Tree Maintenance. 4th ed. New York: Oxford University Press, 1972.

Truex, Philip. The City Gardener. New York: Knopf, 1963.

Wallach, Carla. Gardening in the City:

Backyards, Balconies, Terraces and Penthouses. New York: Harcourt, 1976.
Weaver, Richard E. Jr. A Guide to City Trees in the Boston Area. Jamaica Plain, Mass. Amold Arboretum, 1972.

Weiner, Michael A. Plant a Tree: A Working Guide to Regreening America. New York: Macmillan, 1975.

Westcott, Cynthia. The Gardener's Bug Book. 5th ed. Garden City, N.Y.

Doubleday, 1976.

Wyman, Donald. Shrubs and Vines for American Gardens. rev. ed. New York: Macmillan, 1969

Wyman, Donald. Trees for American Gardens. New York: Macmillan, 1965.

Zion, Rohert L. Trees for Architecture and the Landscape. New York: Van Nostrand, 1968.

"Especially good for young readers

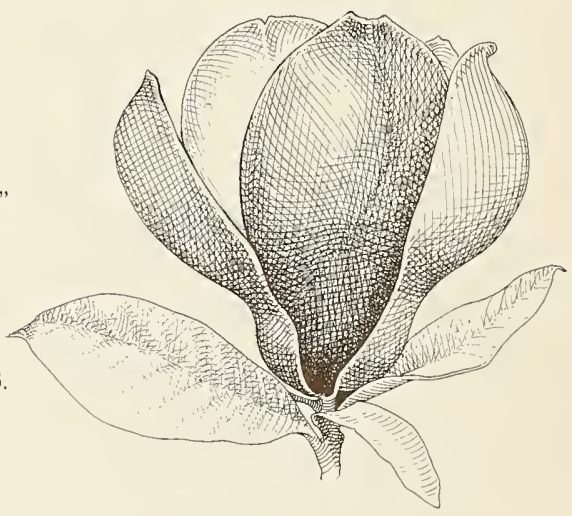

29 


\section{Resources}

\section{The Arnold Arboretum}

The Arborway

Jamaica Plain, Massachusetts

524-1717 Recorded message with informa-

tion on directions, current exhibits, and

displays.

Educational courses and lectures. Open to the public. Fees for members and non-members. Exhibits on display in the Main Administration Building. Open free to the public. Monday through Friday 9 am to $5 \mathrm{pm}$. Library. Publications on gardening and plant identification available for purchase. Staff members available to give assistance on horticultural and botanical problems.

\section{Boston Public Library}

Copley Square and Branches

Books on gardening and horticulture for reference and loan.

\section{Massachusetts Audubon Society}

South Great Road

Lincoln, Massachusetts

$259-9500$

Environmental Information Center. Distributes environmental information materials. Audubon Shop. Large selection of gardening and nature books for purchase. Natural History Services. Operates film library, resource files, and records. Prepares written materials on environmental and natural history subjects.

\section{Massachusetts Horticultural Society} 300 Massachusetts Avenue Boston, Massachusetts $536-9280$

Horticultural library. Some material available for purchase. Open free to the public. Monday through Friday 9 am to 4:40 pm. Educational courses and lectures. Fees for members and non-members. Plant shows and educational exhibits. New England Spring Flower Show. Plant Information Hot Line 536-1720. Free information by horticultural experts. Plant Mobile. Traveling horticultural resource. Trips to schools, senior citizen groups, garden clubs, and business establishments. Horticulture, monthly magazine of the Society.

\section{New England}

Wild Flower Society, Inc.

Hemenway Road

Framingham, Massachusetts

$237-4924$

Resource Center. Clearing house for plant projects and conservation issues. Books and other materials relating to native plants available for purchase. Library. Exhibits.

\section{Suburban Experimental Station}

University of Massachusetts

240 Beaver Street

Waltham, Massachusetts $891-0650$

Free soil testing, insect identification, plant clinic, and advice on gardening problems. Open to the Public Monday, Wednesday, and Friday $8: 30$ am to 12 noon, $1: 00 \mathrm{pm}$ to $4: 00 \mathrm{pm}$

\section{Environmental Programs City of Boston}

The wealth of green spaces that beautify the inner city and neighborhoods of Boston is a distinctive characteristic, one that lends grace to urban living. To preserve the charm and quality of its environment, the city's administration has dedicated itself for a number of years to many citywide and neighborhood-oriented envionmental programs. Among these ongoing programs are:

\section{Air Pollution}

$725-4416$

\section{Control Commission}

Enforces clean air regulations and regulates new parking lots and garages downtown.

\section{Boston} $725-4416$

\section{Conservation Commission}

Protects wetlands and open space, and manages conservation lands.

\section{The Boston Foundation}

The Greening of Boston Program 725-4846 (formerly The Birthday Book Program)
Matching grant program for small-scale neighborhood improvements, trees, and street fumiture. The Greening of Boston: Trees and Shrubs in the City. For further information about this publication, call 725-4846.

Boston

Natural Areas Fund

Acquires and protects natural areas and implements BRA Urban Wilds Report.

Boston

$722-4300$

Redevelopment Authority

Boston Urban Wilds Study

Inventories natural areas in the city and makes recommendations for protecting natural state.

Open Space Management Program Implements site improvement of vacant lots.

Parks and Recreation Department

A Greener Boston $725-4983$

Solicits donations for planting trees in

Boston's neighborhoods.

"Greenthumb"

Offers gardening course for city residents at city greenhouse.

Public

\section{Facilities Department}

\section{REVIVAL/Victory Gardens}

Revitalizes vacant land for urban community gardens.

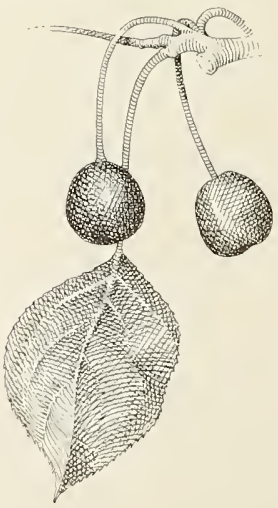




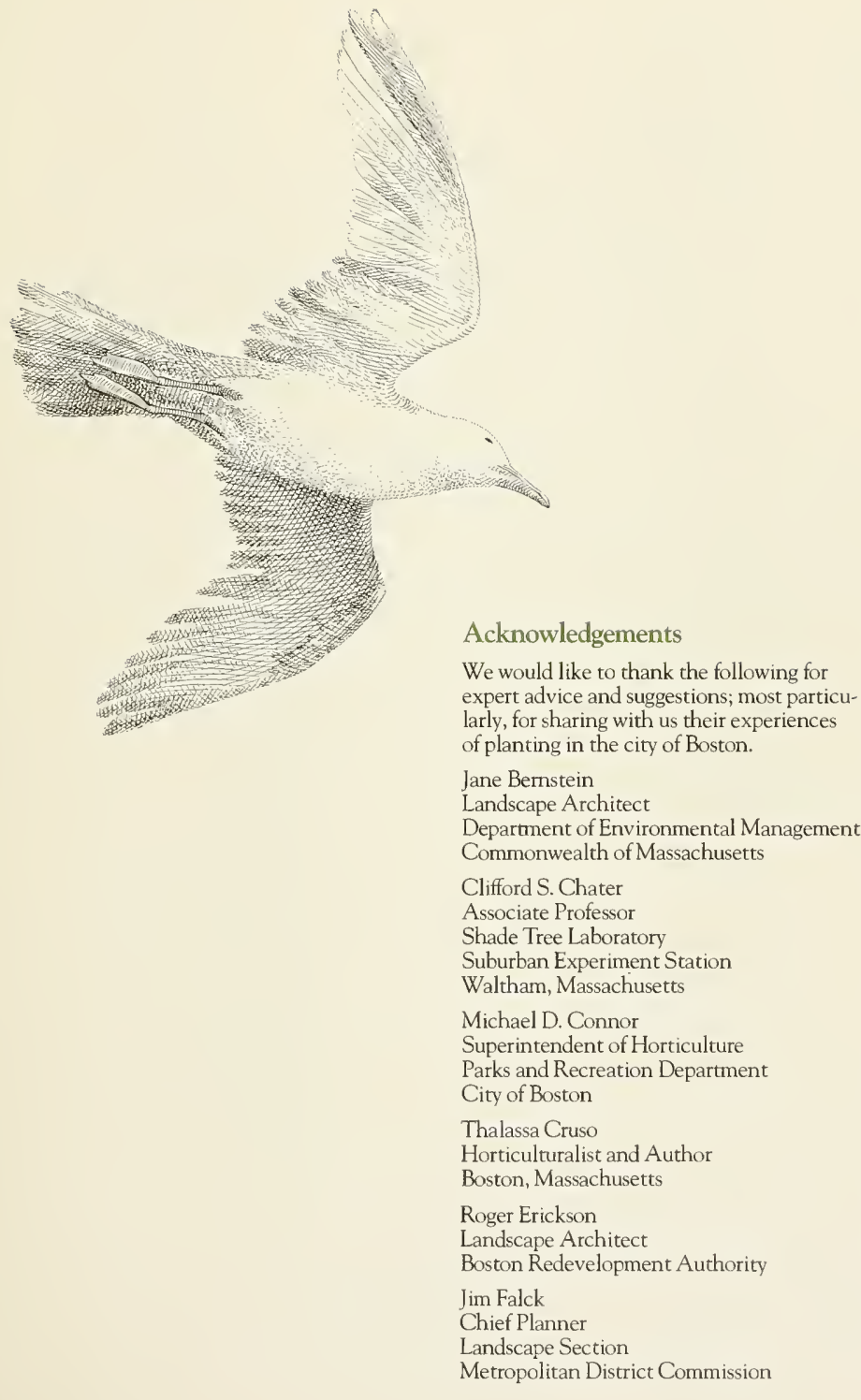

Ruth Foster

Landscape Consultant Belmont, Massachusetts

Joseph B. Glaze

Tree Program Coordinator

Parks and Recreation Department City of Boston

Joseph Hudak

Landscape Architect

Vice President,

Olmsted Associates

Brookline, Massachusetts

Henry Lee

Chairman,

Friends of the Public Garden

Diane McGuire

Landscape Architect

Harvard University

Joseph Volpe

Landscape Architect

Associate Professor

Department of Landscape Architecture and Regional Planning

University of Massachusetts

Richard E. Weaver Jr.

Assistant Curator

Arnold Arboretum

Jamaica Plain, Massachusetts 


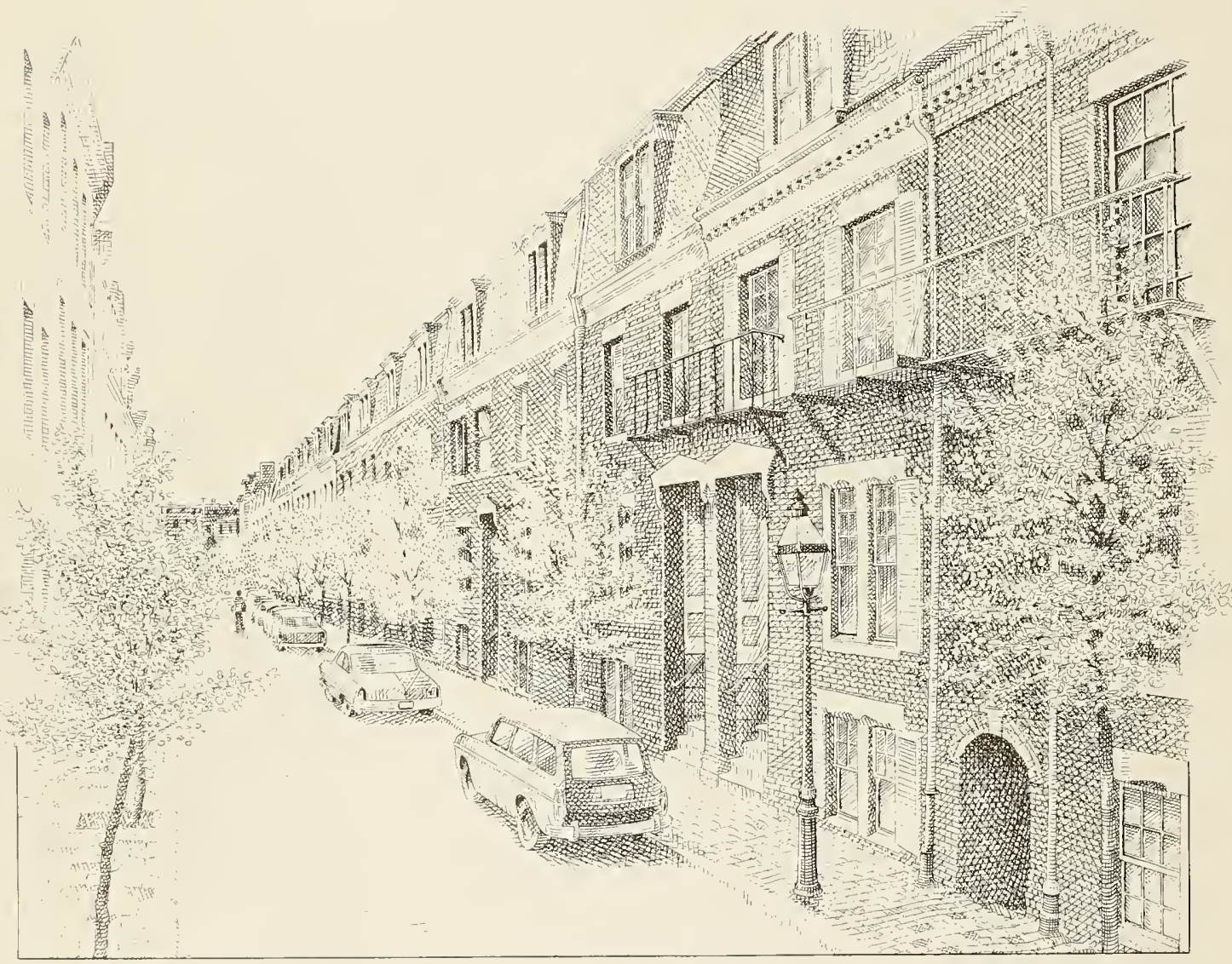

Gier Street, Sinch End

copyright May 1978

Published by the Boston Foundation

Katharine D. Kane, Director, Deputy Mayor

City of Boston/Kevin H. White, Mayor
Project Director, Susan Child

Text, Phyllis Andersen

Illustrator, Laszlo Kubinyi

Designer, Deenie Yudell

Editorial Review, Merloyd Lawrence
Produced with the generous support of the Mabel Louise Riley Trust, Mr. Graham Gund and The Provident 
Card in Front 


$$
\text { ते }
$$

